\title{
SISTEMA DE INFORMAÇÕES APLICADO AO PROCESSO \\ MECANIZADO DE SEMEADURA DIRETA
}

\section{ADRIANO BARBOSA MARQUES DE SOUZA}

\author{
Dissertação apresentada à Escola Superior de \\ Agricultura "Luiz de Queiroz", Universidade de São \\ Paulo, para obtenção do título de Mestre em \\ Agronomia, Área de Concentração: Máquinas \\ Agrícolas.
}

P I R A C I C A B A

Estado de São Paulo - Brasil

Agosto - 2005 


\section{SISTEMA DE INFORMAÇÕES APLICADO AO PROCESSO MECANIZADO DE SEMEADURA DIRETA}

\section{ADRIANO BARBOSA MARQUES DE SOUZA}

Engenheiro Agrícola

Orientador: Prof. Dr. MARCOS MILAN

Dissertação apresentada à Escola Superior de Agricultura "Luiz de Queiroz", Universidade de São Paulo, para obtenção do título de Mestre em Agronomia, Área de Concentração: Máquinas Agrícolas.

P I R A C I C A B A

Estado de São Paulo - Brasil

Agosto - 2005 
Dados Internacionais de Catalogação na Publicação (CIP) DIVISÃO DE BIBLIOTECA E DOCUMENTAÇÃO - ESALQ/USP

Souza, Adriano Barbosa Marques de

Sistema de informações aplicado ao processo mecanizado de semeadura direta / Adriano Barbosa Marques de Souza. - - Piracicaba, 2005.

$75 \mathrm{p}$.

Dissertação (Mestrado) - - Escola Superior de Agricultura Luiz de Queiroz, 2005. Bibliografia.

1. Indicador de qualidade 2. Milho 3. Semeadura direta 4. Sistema de informação gerencial 5. Sistema de produção I. Título

CDD 633.15

"Permitida a cópia total ou parcial deste documento, desde que citada a fonte - O autor" 


\section{DEDICO}

Aos meus queridos pais, José e Olinda.

A minha companheira irmã Carolina.

A minha adorada esposa Adriana.

A meu amado filho André Luiz.

Amo vocês...

OFEREÇO

A aqueles que buscam o conhecimento por meio da informação, porque uma boa ponte não se faz com um único pedaço de madeira. 


\section{AGRADECIMENTOS}

Ao Orientador, Amigo, Companheiro e Professor Doutor Marcos Milan, pela orientação, conselhos e paciência.

Ao Sr. Lúcio Miranda por oferecer a oportunidade e os meios necessários para realização deste trabalho. Aos funcionários da Fazenda Paiquerê: Alisson, Claudinei, Ronaldo, Lineu, Gilmar, Alex, Fábio e todos demais amigos do Paraná pelo auxílio indispensável no trabalho.

Ao pesquisador do IAC Jundiaí, e amigo Afonso Peche Filho, pelo apoio e sugestões dadas durante o decorrer do trabalho.

Ao grande amigo Jorge Murilo pelo auxílio em todas as etapas da caminhada.

A família Viera pelo companheirismo incontestável e aconchego de sua casa.

Aos professores e funcionários do Setor de Máquinas Agrícolas do Departamento de Engenharia Rural da ESALQ/USP, obrigado pelo fundamental apoio pessoal.

Aos amigos e colegas do curso de mestrado em Máquinas Agrícolas, companheiros de lutas e parceiros da NASa (Núcleo dos Alunos da Salinha)

A Tia Dora e a Tia Rosa, minhas tias queridas do coração e seus irmãos, maridos, cunhadas, filhos, sobrinhos, primos e netos que pra minha felicidade são à família.

Aos amigos e compadres de Campo Grande - MS, moçadas de Lavras - MG e turma de Piracicaba - SP que sempre estão presentes em minha vida.

A todos aqueles que, às vezes sem saber, contribuíram para esse trabalho, Obrigado. 


\section{Sumário}

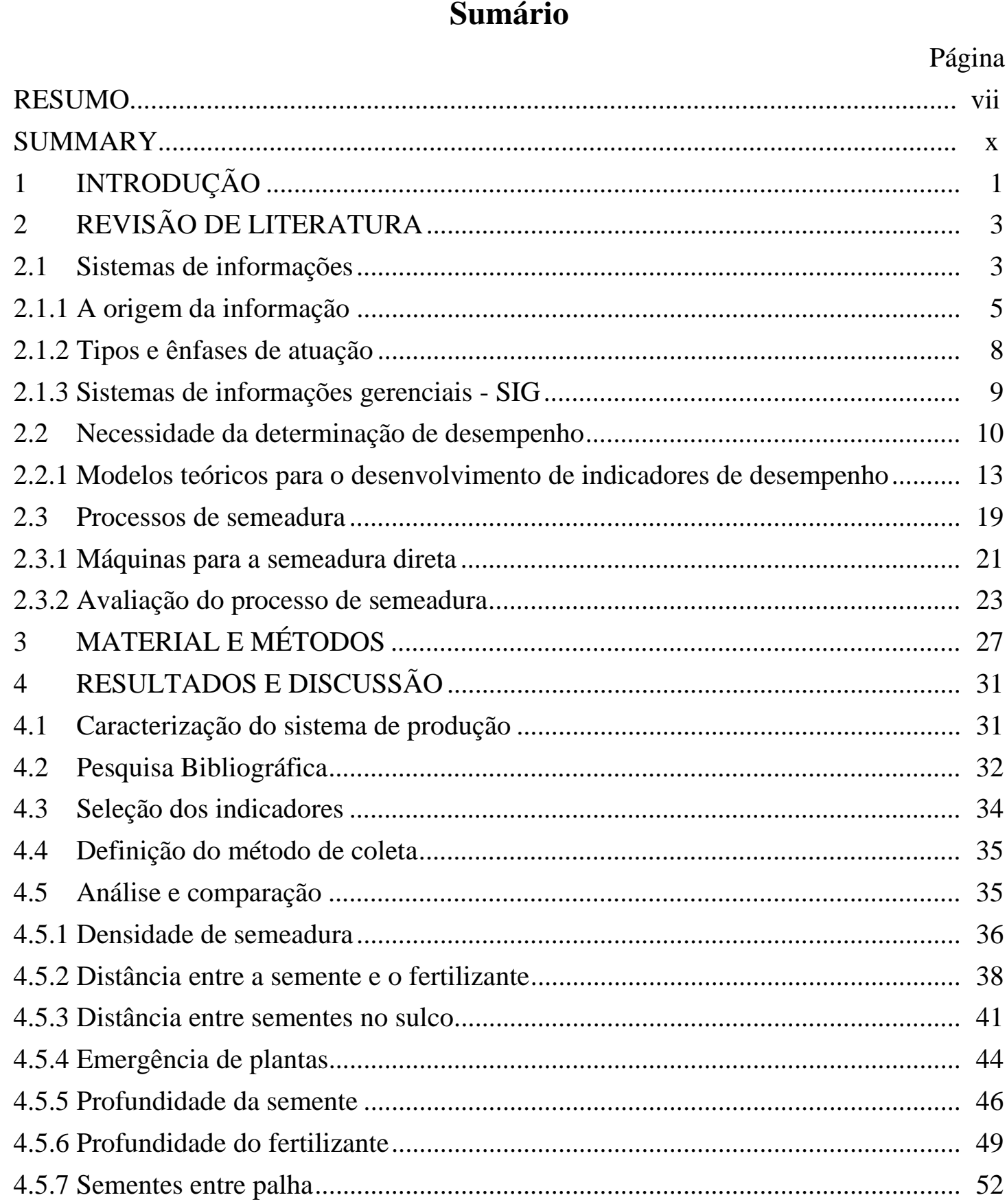




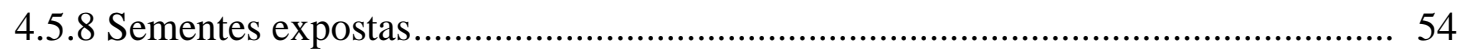

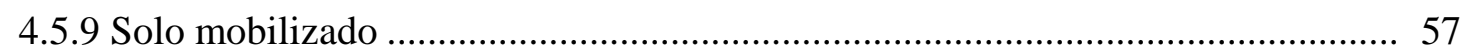

4.6 Índice de Qualidade do Processo (IQP) _...................................................... 58

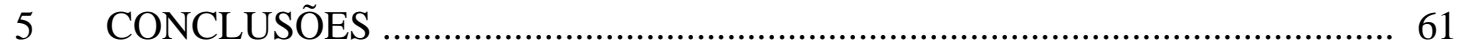

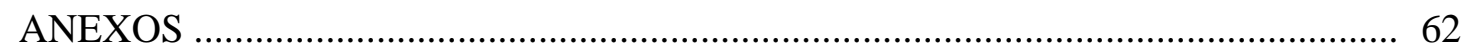

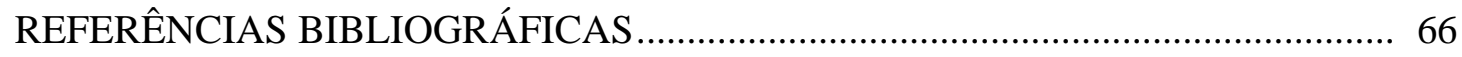

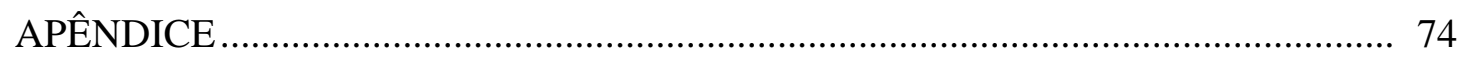




\title{
SISTEMA DE INFORMAÇÕES APLICADO AO PROCESSO MECANIZADO DE SEMEADURA DIRETA
}

\author{
Autor: ADRIANO BARBOSA MARQUES DE SOUZA
}

Orientador: Prof. Dr. MARCOS MILAN

\section{RESUMO}

Considerando que a informação representa um papel estratégico para a sobrevivência das empresas, que a agricultura necessita desenvolver indicadores básicos para os seus processos de produção e que a semeadura é um processo decisivo no ciclo da cultura, o objetivo deste trabalho foi desenvolver e aplicar indicadores para avaliar a qualidade dos processos de produção agrícola, tendo como base a semeadura direta em um sistema de produção de milho. O estudo foi realizado em uma propriedade agrícola do Grupo Lúcio Miranda, no município de Piraí do Sul, Estado do Paraná. Para a avaliação do sistema produtivo em questão, foram utilizados indicadores de desempenho e limites de especificação para cada indicador. Foram utilizadas na avaliação dos resultados, ferramentas de análise estatística descritiva, em seguida foi determinado um índice para cada indicador (Iind) e um geral para o processo (IQP). A metodologia proposta permitiu obter um sistema de informações para o processo de semeadura direta do milho. O IQP identificou que o processo necessita de melhorias, e por meio do Iind 
realizou-se a análise individual de cada indicador detectando aqueles que influenciaram negativamente a qualidade da operação.

PALAVRAS-CHAVE: indicadores operacionais, milho, qualidade. 


\title{
INFORMATION SYSTEM APPLIED TO THE MECHANIZED PROCESS OF DIRECT DRILLING
}

\author{
Author: ADRIANO BARBOSA MARQUES DE SOUZA
}

Adviser: Prof. Dr. MARCOS MILAN

\section{SUMMARY}

Considering that the information represents a strategic role for the companies survival and that agriculture needs to develop basic indicators for its production processes and that sowing is a decisive process in the crop cycle, the objective of this work was to develop and to apply indicators to evaluate the quality of the processes agricultural production processes, having as basis the no-till system of maize production. The study was carried in an agricultural property of the Lúcio Miranda Group, in the city of Piraí do Sul, State of the Paraná. For the evaluation of the productive system in question, performance measurement and specification limits were used for each indicator. Tools of descriptive statistical analyses were used in order to evaluate the results, after that it was determined an index for each indicators (Iind) and a general one for the process (IQP). The proposed methodology allowed getting an information system for the process of the maize direct sowing. The IQP identified that the process needs 
improvements, and by through the Iind it was done the individual analysis of each indicator detecting those that had negatively influenced the quality of the operation.

KEY WORDS: operational indicators, maize, quality. 


\section{INTRODUÇÃo}

O panorama mundial demonstra que, na transição de uma sociedade industrial para uma sociedade de informação, a capacidade de gerar, analisar, controlar e distribuir as informações, passa a ser um ponto estratégico para as organizações, já que mudanças significativas nos ambientes interno e externo das empresas, provocadas pela alta competitividade do mercado, levaram à necessidade de rapidez na informação para tomada de decisão. Assim, os dirigentes passaram a utilizar a informação como ferramenta estratégica para o planejamento, coordenação e controle, além do acompanhamento do mercado sob os aspectos econômicos, legais, políticos e culturais, contribuindo para a sobrevivência das empresas.

Frente a essa nova realidade, a elaboração de um Sistema de Informações (SI) com indicadores operacionais dos processos que auxiliem nas funções de planejamento, controle e tomada de decisão tornam-se fundamentais, pois visam identificar as áreas onde os processos apresentam diferenças entre o planejado e o realizado.

Apesar da bibliografia apresentar várias recomendações e modelos conceituais de SI, são raros os trabalhos dirigidos para a área agrícola que tratam sobre como desenvolver e montar ordenadamente indicadores operacionais nos processos de produção. A agroindústria sucroalcooleira provavelmente foi a primeira a utilizar indicadores para obtenção de informações de seus processos agrícolas, sendo seguida por empresas citrícolas e florestais, que muito se assemelham às indústrias.

Com o surgimento de inovações nas tecnologias de produção, como o sistema de semeadura direta que eliminou as operações de aração e gradagem no preparo do solo, atribuindo a semeadura uma importância relevante no processo agrícola. Essas novas técnicas aliadas à utilização de SI na agricultura possibilitam o monitoramento das operações de campo necessário para minimizar as perdas decorrentes da variabilidade. 
Considerando-se que a informação representa um papel estratégico para a sobrevivência das empresas, que a agricultura necessita desenvolver indicadores básicos para os seus processos de produção e que a semeadura é um processo decisivo no ciclo da cultura, o objetivo deste trabalho foi desenvolver e aplicar indicadores para avaliar a qualidade dos processos de produção agrícola, tendo como base a semeadura direta em um sistema de produção de milho. 


\section{REVISÃO DE LITERATURA}

\subsection{Sistemas de informações}

A palavra sistema envolve um grande volume de idéias. Uma definição mais abrangente de sistema é a de um conjunto ou combinação de componentes ligados ou interdependentes e que interagem de modo a formar uma unidade complexa, um todo composto de partes de uma forma organizada, segundo um esquema ou plano para atingir um objetivo global (Chiavenato, 2000). O conceito de sistemas, como um conjunto de partes orientado a um objetivo comum foi baseado no estudo de organismos vivos.

Os sistemas apresentam alguns componentes (Figura 1), os objetivos, que se referem tanto aos objetivos dos usuários do sistema, quanto aos do próprio sistema. As entradas, cuja função caracteriza as forças que fornecem ao sistema o material, a energia e a informação. O processo de transformação, que é definido como a função que possibilita a transformação de um insumo (entrada) em um produto, serviço ou resultado (saída). As saídas correspondem aos resultados dos processos de transformação. Os controles e avaliações existem principalmente para verificar se as saídas estão coerentes com os objetivos estabelecidos. A retroalimentação ou feedback pode ser considerado como a reintrodução de uma saída sob a forma de informação (Oliveira, 1992). 


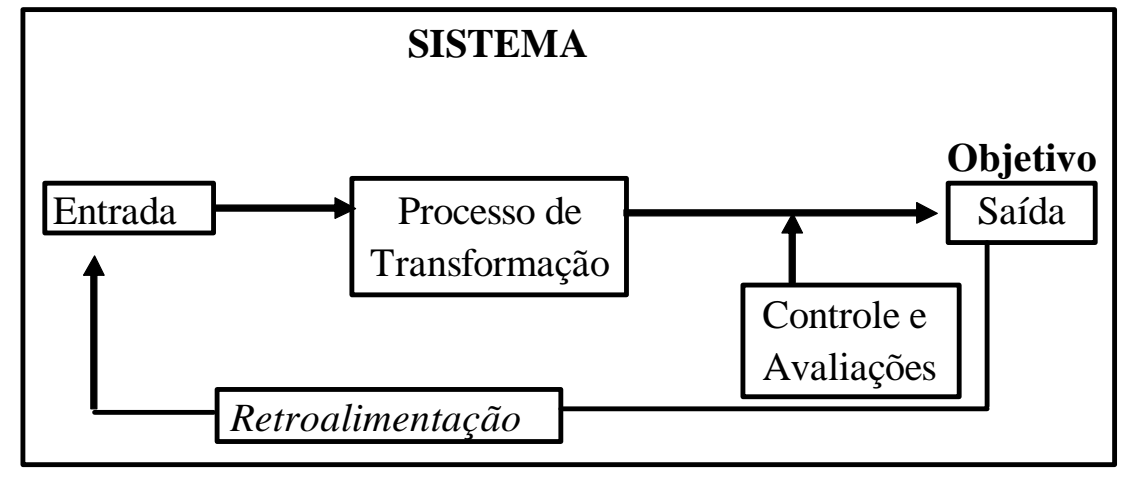

Figura 1 - Sistema e seus componentes, adaptado de Oliveira (1992)

Esta visão também é compartilhada por Farinha (2004), quando acrescenta que um sistema pode ser qualquer conjunto de componentes e processos, que visa transformar determinadas entradas em saídas. Entrada pode ser definida como sendo todos os elementos que o processo deve receber para a transformação em saída, um conjunto de insumos que deve ser processado para obter os resultados, estando em geral, diretamente relacionados ao objetivo ou razão do processo. A todo sistema deve ser relacionada a razão de sua existência. Essas razões constituem-se os objetivos do sistema e estão relacionadas às saídas que são produzidas.

Bonilla (1991) considera processo como “algo que está em constante movimento” (transformação), sendo considerado como um conjunto de causas operando sobre certos insumos, objetivando um efeito final. Por outro lado, os processos correspondem a diversos níveis, de modo que uma empresa agrícola pode ser considerada como um processo global, mas dentro existem processos menores, departamentos ou seções e ainda dentro destes, processos menores ainda até chegar aos processos básicos, preparo do solo, adubação, colheita. $\mathrm{O}$ fato de que os processos sejam divisíveis em processos menores é extremamente vantajoso, pois o gerenciamento dos mesmos fica muito facilitado.

Os sistemas de informações podem auxiliar as empresas a sanarem um dos grandes problemas dos dias de hoje, a necessidade de informações internas e externas em um curto espaço de tempo (Perottoni et al., 2004). 
Schmoeckel (2002) afirma que é necessário na elaboração de um sistema de informações, antever que tipo de resposta será demandado mais freqüentemente. Isso é importante para que se tenha um sistema para auxiliar na maioria das decisões o tempo todo, e não um banco de dados com muitos indicadores sobre questões diversas da operação, mas que individualmente não atendem as necessidades. O autor salienta que este sistema não será formado por dados disponíveis, mas sim, por um conjunto de “dados exigidos” que responderá a um elenco de perguntas de modo confiável. Quanto mais amplo o escopo de perguntas respondidas, mais poderoso o sistema.

\subsubsection{A origem da informação}

Muitas são as propostas e teorias que visam definir a informação tanto falada na sociedade contemporânea. Alguns argumentam dizendo que é apenas uma coleta de dados, porém a informação não se limita apenas a dados coletados, mas, coletados, organizados, ordenados, aos quais são atribuídos significância e contexto (McGee, 1994). O autor caracteriza que a informação deve informar.

Dados são os fatos em sua forma primária e a mudança para informação é denominada de processo. A informação pode ser definida como um conjunto de fatos organizados de tal forma que adquirem valor adicional além do valor em si. A transformação gera o conhecimento, que pode ser considerado como o corpo ou as regras, diretrizes e procedimentos usados para selecionar, organizar e manipular os dados, para torná-los úteis para uma tarefa específica. O ato de seleção ou rejeição dos fatos, baseados na sua relevância em relação às tarefas particulares é também um tipo de conhecimento usado no processo de conversão de dados em informação (Farinha, 2004).

Dado, informação e conhecimento, embora interdependentes, não são conceitualmente iguais. A informação propicia um conhecimento ao tomador de decisão, o que não acontece quando se utilizam apenas dados. Embora os dados sejam apresentados como fonte primária de informação, isoladamente eles não apresentam esse significado (Lapolli, 2003). Segundo o autor, a transformação de informação em conhecimento e como transferir e utilizar este conhecimento são os maiores desafios das organizações, (Tabela 1). 
Tabela 1. Conceito de dado, informação e conhecimento

\begin{tabular}{|c|c|c|}
\hline DADO & INFORMAÇÃO & CONHECIMENTO \\
\hline $\begin{array}{l}\text { Simples observação sobre o } \\
\text { estado do mundo }\end{array}$ & $\begin{array}{c}\text { Dados dotados de relevância e } \\
\text { propósito }\end{array}$ & $\begin{array}{l}\text { Informação valiosa do } \\
\text { homem. Compreende, } \\
\text { reflexão, síntese e contexto. }\end{array}$ \\
\hline Facilmente estruturado & Requer análise & Difícil estruturação \\
\hline $\begin{array}{c}\text { Facilmente obtido por } \\
\text { máquinas }\end{array}$ & $\begin{array}{c}\text { Exige consenso sobre o } \\
\text { significado }\end{array}$ & Difícil captura em máquinas \\
\hline $\begin{array}{l}\text { Freqüentemente quantificado } \\
\text { Facilmente transferível }\end{array}$ & Exige a intervenção humana & $\begin{array}{l}\text { Freqüentemente tácito } \\
\text { Difícil transferência }\end{array}$ \\
\hline
\end{tabular}

Fonte: Davenport \& Prusak (1998) ${ }^{1}$ citados por Lapolli (2003)

Albrecht (1999), caracteriza que dado, informação, e conhecimento diferem entre si: dado é o nível simbólico irredutível, inerte e pode ser armazenado e transportado a despeito do seu significado; informação é à disposição dos dados de modo que façam sentido para as pessoas; conhecimento é o conteúdo de valor agregado do pensamento humano, que deriva da percepção e manipulação inteligente da informação.

Segundo Oliveira \& Perez Junior (2000) ${ }^{2}$ citado por Schmoeckel (2002), dado é qualquer elemento identificado em sua forma bruta, potencialmente útil, mas que não tem valor imediato, pois por si só, não conduz a uma compreensão de determinado fato, ou situação. Portanto, informação é o dado trabalhado que permite ao executivo tomar decisões. Como exemplos de dados em uma empresa, citam-se quantidade de produção, custo de matéria-prima, número de empregados. A informação seria o resultado da análise desses dados, ou seja, capacidade de produção, custo de venda do produto, produtividade do funcionário.

Com a rápida evolução da informática e eletrônica verificada nos últimos anos a

\footnotetext{
${ }^{1}$ DAVENPORT, T. H.; PRUSAK, L. Ecologia da informação: Porque só a tecnologia não basta para o sucesso na era da informação. São Paulo: Futura, 1998. 316 p.

2 OLIVEIRA, L.M. de, PEREZ JUNIOR., J.H. Contabilidade de custos para não contadores. São Paulo: Editora Atlas, 2000. 320 p.
} 
coleta e processamento de dados se tornaram uma tarefa menos complicada (Lapolli, 2003), e com a propagação da rede mundial de computadores (Internet), permitiu o transporte e compartilhamento de dados de forma muito abrangente e rápida. Porém o computador não é a única maneira, pois segundo Farinha (2004) existem outros meios de se processar o dado dentro da organização, podendo ser feito mentalmente e manualmente.

A evolução da informática permitiu a informatização da coleta, acumulação e análise de dados, entretanto, não garante sucesso na implantação de um Sistema de Informações. Os dirigentes da empresa, estudada por Stevanato (1995), agiam como se o fato de ter comprado computadores novos fosse resolver os problemas da empresa. Esqueciam o detalhe de que o computador precisa de dados corretos e confiáveis para gerar as informações necessárias. Todavia, um sistema de informações não necessariamente está relacionado com o uso de computadores, podendo ter um sistema eficiente se utilizando meios manuais.

O grande desafio do momento atual é transformar o grande volume de dados e informações em conhecimento que auxilie na tomada de decisão. A importância deve ser dada para que os resultados sejam úteis e de valor, para poder tomar as decisões certas. Para que os dados se tornem úteis como informação para uma pessoa que seja responsável pelo processo decisório da organização, é preciso que sejam apresentados de tal forma que essa pessoa possa relacioná-los e atuar sobre eles (McGee, 1994).

Cautela e Polloni (1986) ${ }^{3}$ citados por Lapolli (2003), apresentam algumas características necessárias à informação. Os autores dizem que as informações devem ter clareza, serem precisas, de forma rápida, dirigida e Farinha (2004) complementa dizendo que ainda devem ser completas, econômicas, flexíveis, confiáveis, simples e em tempo.

A informação é valiosa se for pertinente à situação, fornecida no tempo certo, para as pessoas certas de forma não complexa demais para ser entendida, precisa e completa e de custo compatível. Stevanato (1995) ressalta que na medida que uma

\footnotetext{
${ }^{3}$ CAUTELA, A.L.; POLLONI, E.G. F. Sistemas de informação - técnicas avançadas de computação. São Paulo: McGraw-Hill, 1986. 272 p.
} 
empresa começa a coletar dados para a informação há uma grande mudança em sua estrutura gerencial com conseqüente reflexo no processo decisório.

Goldratt (1992) ${ }^{4}$ citado por Schmoeckel (2002) lembra que definir informação não como o dado requerido para responder a pergunta, mas como a resposta à pergunta feita. Portanto, há uma ponte entre o dado e a informação necessária e, conseqüentemente, a natureza de um sistema concebido para ser Sistema de Informação, será distintamente diferente de um Sistema de Dados.

Oliveira (1992) afirma que a informação produzida não sendo distribuída em tempo hábil para tomada de decisão, praticamente perde o sentido. Sua capacidade de reduzir incertezas está associada com a oportunidade de sua distribuição.

Resumidamente, Oliveira (2004) define que a informação é a consolidação de poder na empresa, desde o momento da aquisição e posse dos dados básicos que serão posteriormente transformados, até a possibilidade de otimizar conhecimentos técnicos, domínios de políticas e possibilidade de maior especialização e conseqüente respeito profissional ao executivo considerado.

\subsubsection{Tipos e ênfases de atuação}

Nos anos 50 começaram a surgir os primeiros sistemas de informações computadorizados, os quais focavam o nível operacional da organização. Com o passar do tempo, outros tipos de sistemas vieram agregar-se aos anteriores, atendendo diferentes necessidades das organizações (Lapolli, 2003). O autor classifica os sistemas de informações da seguinte forma:

Sistema de Processamento de Transações (TPS ou SIT) - controla as transações;

Sistema de Informação Gerencial (MIS ou SIG) - fornece informações associadas aos subsistemas funcionais;

Sistema de Automação de Escritório (OAS ou SAE) - faz o processamento de textos, agendas eletrônicas, editores de imagens, entre outros;

Sistema de Apoio à Decisão (DSS ou SAD) - realiza simulações com a utilização

\footnotetext{
${ }^{4}$ GOLDRATT, E.M.A Síndrome do palheiro: garimpando informação num oceano de dados. São Paulo: Educator - Editora e IMAN - Instituto de Movimentação e Armazenagem de Materiais, 1992. 365 p.
} 
de modelos para dar suporte às decisões;

> Sistema Especialista (ES ou SE) - prioriza o acúmulo de conhecimento visando substituir o julgamento humano;

Sistema de Informação para Executivos (EIS ou SIE) - atenta na visão da organização como um todo, por meio de fatores críticos de sucesso;

Sistema de Gestão Empresarial (ERP ou SGE) - realiza a integração das funções encontradas no SIT, SIG e EIS;

Data warehouse / Data mining (DW/DM) - exploração dos dados gerados pela empresa;

Customer Relationship Management (CRM) - atenção no relacionamento com o cliente, de forma individual.

Cada sistema possui uma ênfase específica, podendo seus usuários, serem diferenciados pelos níveis hierárquicos da empresa, contendo assim características próprias (Oliveira, 2004).

\subsubsection{Sistemas de informações gerenciais - SIG}

Pode-se conceituar Sistema de Informações Gerenciais (SIG) como sendo um conjunto de sistemas de informações interagindo e fornecendo informações a todos os níveis da organização (Lapolli, 2003). Oliveira (2004) conceitua os SIGs como sistemas que dão suporte ao nível gerencial da empresa, proporcionando suporte às funções de planejamento, controle e tomada de decisões. Estes sistemas quase sempre são dependentes de sistemas processadores de transações.

Um SIG coleta, valida, executa operações, transforma, armazena e apresenta informações para o uso do planejamento e orçamento, entre outras situações gerenciais, esse sistema extrai as informações de base de dados compartilhados e de processos que estão de acordo com o que o SIG necessita para sua operação. Após a coleta dos dados e transformação dos mesmos em informação, a principal função do sistema é de prover o gerente com informações passadas e presentes sobre as operações internas e sobre o ambiente da empresa, orientando-o para as tomadas de decisão gerenciais, assegurando 
que as estratégias do negócio tragam frutos de modo eficiente, fazendo com que os objetivos traçados sejam alcançados de modo satisfatório (Perottoni et al., 2004), tornando-se uma importante ferramenta administrativa para o gerente.

Oliveira (1992) já ponderava sobre o SIG como instrumento de maior importância administrativa dentro da empresa, pois serve para otimizar as comunicações e o processo decisório, que são problemas sérios para a eficiência e eficácia das empresas, devido a falta do fluxo da informação.

O principal objetivo de um SIG é disponibilizar informações para a tomada de decisões, ou seja, são sistemas tipicamente fornecedores de relatórios. Isto para garantir a sobrevivência da organização em um ambiente competitivo e sujeito a mudanças constantes (Lapolli, 2003).

Os SIGs segundo Oliveira (1992), podem ser classificados de acordo com as necessidades básicas das empresas em quatro tipos:

SIG defensivo: orientado para a obtenção de informações do ambiente externo destinada a evitar surpresas desagradáveis;

> SIG inativo: dirigido para obtenção de parâmetros de avaliação do desempenho;

> SIG ofensivo: aponta as oportunidades de negócio;

$>$ SIG interativo: tem a função de criar oportunidades de negócio.

Manas (1999) considera para a classificação dos SIGs, a necessidade de informação gerencial envolvida no processo decisório da empresa. O autor coloca apenas duas divisões básicas: a primeira trata o SIG como um Sistema de Apoio Operacional, que possui a responsabilidade de processar transações, baseados em procedimentos rotineiros; a segunda como um Sistema de Apoio a Tomada de decisão, que auxilie o processo de decisão com informações provinda de indicadores do desempenho da empresa.

\subsection{Necessidade da determinação de desempenho}

Segundo o manual de técnicas e ferramentas do Departamento de Energia dos Estados Unidos (USA-DoE, 1997), as medidas de desempenho permitem conhecer como 
as coisas estão sendo feitas, se as metas estão sendo atingidas, se os clientes estão satisfeitos, se os processos estão sob controle e onde o processo de melhoria é necessário.

Para compreender o que são indicadores de desempenho, é necessário considerar que as pessoas responsáveis pela direção de um negócio necessitam informações que lhes permitam saber, num dado momento, como o mesmo está sendo conduzido, para que possam manter o seu andamento, corrigir eventuais distorções ou, ainda, alterá-lo radicalmente (Robbins, 2000). O autor cita que tais informações necessárias ao processo decisório, podem ser chamadas de medidas ou indicadores de desempenho e que as fontes de informação mais utilizadas para obtê-los são: observação pessoal; relatórios estatísticos; informes verbais; relatórios escritos; bancos de dados acessados por computador.

As métricas, conjunto de medidas, não devem ser sentenciadas simplesmente como rápidas, ótimas e perfeitas, porém como indicadores que ofereçam um dimensionamento dos outputs (produtos e serviços) e de seus processos, como por exemplo: percentagem, volume, quantidade, etc., sendo eficazes e capazes de expressar um resultado abrangente. É necessário ainda ser entendido que essas medidas e seus parâmetros podem ser mudadas com o tempo, devendo ser constantemente avaliadas (Furhmann, 2003).

Moreira (1996a), cita que as medidas podem ser feitas para os principais departamentos ou divisões e mesmo para os principais processos ou atividades, constituindo-se numa forma capaz de acompanhar o efeito de planos específicos de melhoria de desempenho. Para Alt \& Martins (2000), um conceito de desempenho é uma maneira de medir em uma determinada área, e de agir sobre os desvios em relação aos objetivos traçados. Já para Hronec (1997), este conceito são os sinais vitais da organização que qualificam e quantificam o modo como as atividades ou 'outputs' de um processo atingem suas metas, assim, as medidas de desempenho respondem à pergunta: como você sabe?

Robbins (2000), trabalhou com medidas de desempenho em sistemas logísticos e, concluiu que, como o valor de um serviço depende, em grande parte, da percepção do 
cliente. A medida é na maioria das vezes qualitativa, pois um gerente pode descobrir pistas importantes sobre problemas potenciais a partir da expressão facial ou comentários casuais de um empregado, que poderia não ser evidente na análise de um relatório estatístico, mas que, por outro lado, geralmente contêm dados mais abrangentes e objetivos. Embora as medidas de desempenho não sejam um fim em si mesmas, elas são fundamentais para permitir à direção da organização determinar um posicionamento competitivo estratégico como forma de garantir o sucesso mercadológico.

Para Nauri (1998), as melhores medidas de desempenho são como um sistema de alerta, que envolve prevenção e identificação, direcionado à obtenção da melhor adequação ao uso dos produtos e/ou serviços e da satisfação dos clientes. Por isso, na opinião do autor, em todo processo de medição, os resultados devem ser constantemente relatados aos envolvidos, de forma que todos possam acompanhar a evolução do nível de serviço e promover as devidas alterações, quando necessárias, a fim de se manter e alcançar as metas estabelecidas anteriormente.

Muitas vezes, as empresas implantam medidas de desempenho que não são entendidas pelas pessoas e, conseqüentemente, não produzem os efeitos desejados, não conduzem à ação, e não levam à adoção de medidas corretivas.

O uso de medidas de desempenho é essencial para que se possa avaliar os resultados e atuação de uma empresa, deve refletir os princípios básicos da organização (Harrington, 1997). Para isso, é necessário que sejam estabelecidas metas a serem atingidas e medidas de desempenho a serem calculadas. Porém, conforme relata Nauri (1998) em seu trabalho, o uso indiscriminado de medidas de desempenho deve ser evitado, pois a definição e implementação dessas medidas geram custos para a organização. Deve-se, portanto, utilizar o processo de medição somente nas áreas em que a empresa for mais deficiente.

Porém, é necessário encarar a avaliação de desempenho sempre como um processo de gestão, é preciso compreender que o contexto empresarial é dinâmico e mutável. Sendo assim, as empresas devem estar constantemente adaptando-se às transformações ambientais que ocorrem, pois do ponto de vista do fornecedor de serviços, a chave para a medida precisa pode ser o entendimento dos fatores críticos de 
sucesso do negócio do cliente (Bowersox \& Closs, 1996).

Portanto, medir desempenho significa mensurar, medir e comparar em relação a padrões ou objetivos pré-estabelecidos. Além disso, para que uma mensuração apresente utilidade, ela deve permitir a adoção de medidas corretivas, mensuração sem ação é desperdício, perda de tempo que não conduz a lugar algum. Segundo Alt \& Martins (2000), as medidas de desempenho devem ser claramente compreendidas por todos os envolvidos (clientes e fornecedores), serem reprodutíveis nas mesmas condições e, ainda, orientadas para resultados.

Segundo Rey (1999), aquilo que não se mede, não se melhora. Torna importante para a organização ter um conjunto de indicadores de desempenho em diversos níveis, sejam financeiro, produtivo, qualidade e tempo. O que fatalmente ira conduzir a comportamentos e relações de trabalho sólidas, medidas pelo objetivo comum de proporcionar a melhor estratégia possível que otimize os fluxos de materiais, informação e dinheiro entre fornecedores e consumidores.

Para Moreira (1996b), os gerentes necessitam de um modelo de avaliação do desempenho que permita identificar, medir e gerir o menor número possível de indicadores, seja através de sistemas simples ou sofisticados, mas que esteja de acordo com o que os usuários necessitam.

\subsubsection{Modelos teóricos para o desenvolvimento de indicadores de desempenho}

A construção de indicadores para avaliação de processos é um trabalho que exige uma equipe interdisciplinar, pois não é uma formula pronta, é necessário análise, interpretação e compreensão por parte dos envolvidos. Deponti et al. (2002) consideram que os indicadores que descrevem um processo específico são particulares a esses processos, e por isso não há um conjunto de indicadores globais adaptáveis a qualquer realidade.

Existem organizações que selecionam seus indicadores de maneira intuitiva, sem considerar nenhum critério específico, alguns desses estão na empresa por tradição e outros porque a alta direção exige. A apresentação dos indicadores mostra um certo caráter fortuito nestas organizações, e a forma de apresentação mais comum é a lista de 
indicadores da alta direção, classificadas por perspectivas ou apenas por uma diretoria responsável (FPNQ, 2002).

Martins \& Costa Neto (1998) destacam que os indicadores de desempenho são um meio para auxiliar a gestão pela qualidade total, mas não são uns fins em si mesmos. Eles são úteis para que o sistema de gestão possa controlar e identificar necessidades e melhorar o desempenho, fatores estes que estão relacionados à satisfação dos clientes, empregados, acionistas, sociedade e fornecedores da empresa, em todos os níveis de gerência da empresa, conforme a Figura 2.

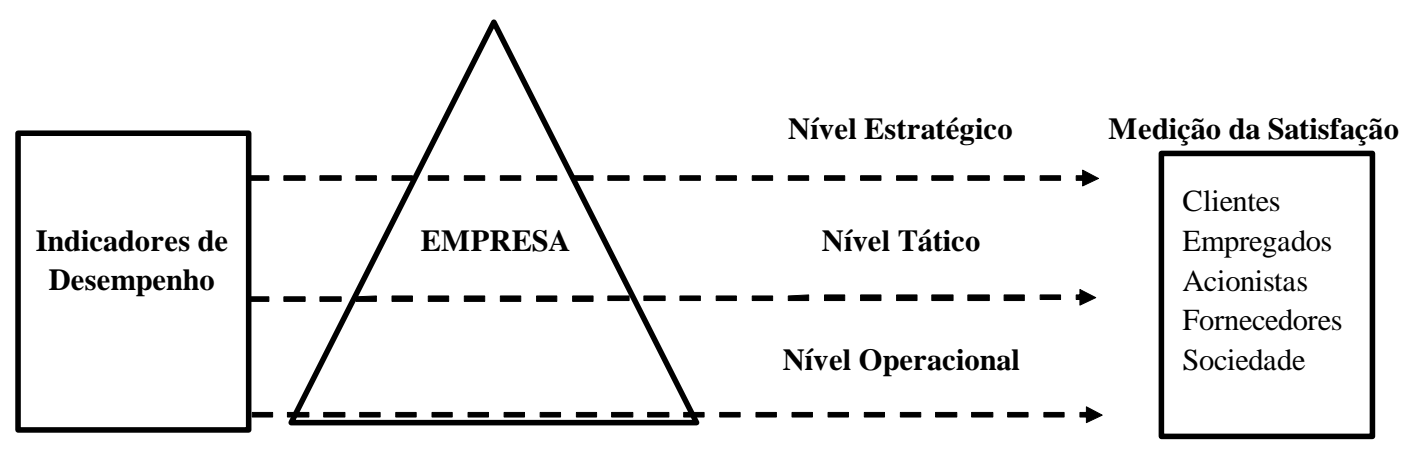

Figura 2 - Proposta de sistematização de indicadores de desempenho para a gestão pela qualidade total, adaptada de Martins \& Costa Neto (1998)

Kiyan (2001) apresenta uma proposta para desenvolvimento de indicadores de desempenho como suporte estratégico que incorpora duas idéias que orbitam na área de medição de desempenho: alinhamento dos esforços organizacionais e relação entre os indicadores. A primeira refere-se ao direcionamento das ações de melhorias em processos considerados críticos dentro da empresa, para alavancar a estratégia competitiva adotada. A segunda consiste em trabalhar o conceito de medição de desempenho não só com relação aos indicadores de uma forma isolada, mas também entender como eles relacionam entre si e o quão aderente este conjunto de indicadores é em relação aos objetivos organizacionais. A proposta foi estruturada de modo a ter um caráter abrangente, não se restringindo aos modelos de sistemas de medição de desempenho propostos na bibliografia, Figura 3. 


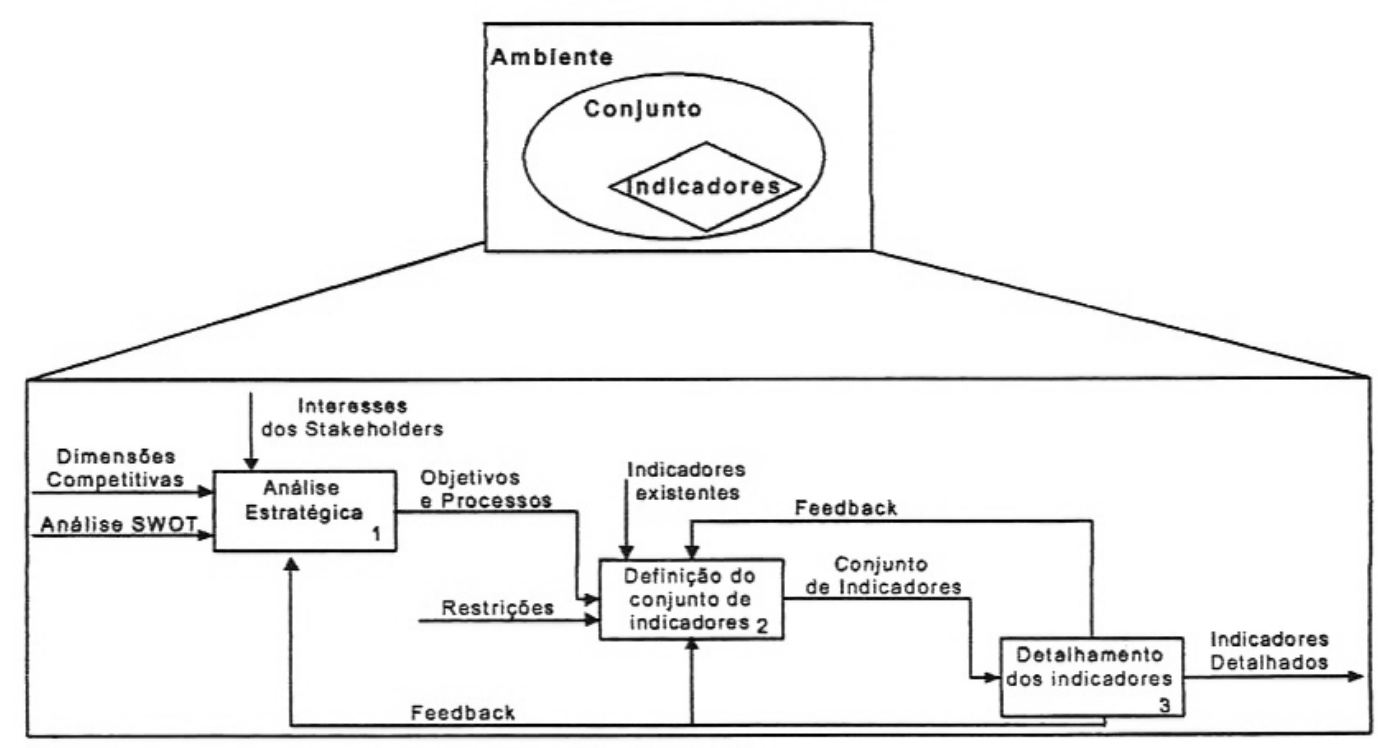

Figura 3 - Estrutura macro da proposta apresentada por Kiyan (2001)

Na Figura 3, em cada nível de análise, ocorrem várias atividades que podem ser agrupadas em uma série de passos. A etapa 1, análise estratégica, visa determinar quais são os objetivos estratégicos da empresa e quais processos organizacionais que a empresa deve concentrar grande parte do esforço. A etapa 2, definição do conjunto de indicadores, procura determinar os indicadores mais adequados para com os objetivos estratégicos estabelecidos anteriormente. A etapa 3, detalhamento dos indicadores, detalha e específica os indicadores selecionados.

Hronec (1997) traz o conceito de desempenho quantum, que pode ser definido como o nível de realização que otimiza o valor e o serviço da organização para seus interessados: cliente, empregados, acionistas, fornecedores, etc. Este sistema de medição é composto basicamente por uma matriz de desempenho, chamada de quantum, que permite a administração entender e desenvolver medidas de desempenho que venham a equilibrar três dimensões de desempenho: qualidade, tempo e custo. Para determinação das medidas de desempenho, dentro das áreas compreendidas na matriz, faz-se necessário o uso do processo chamado de "O modelo quantum de medição de desempenho”, que fornece a estrutura básica para a medição de desempenho, Figura 4. 


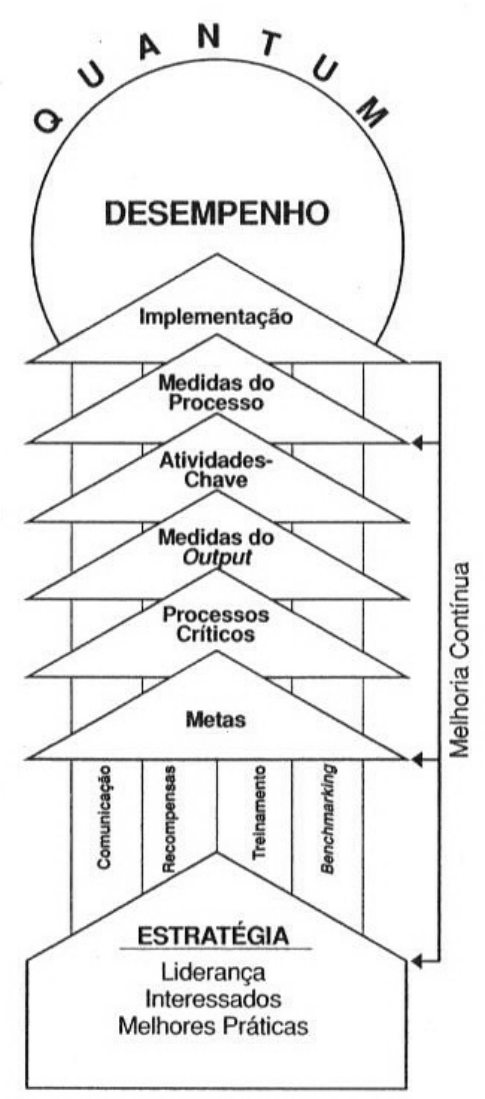

Figura 4 - Modelo Quantum de medição de desempenho (Hronec, 1997)

Kaplan \& Norton (1997) desenvolveram, a partir de estudos realizados junto a grandes empresas norte-americanas, o Balanced Scorecard (BSC) no início da década de 90. O BSC é uma abordagem da medição de desempenho que combina métricas financeiras com não financeiras, com o intuito de fornecer informações mais relevantes sobre as atividades. A elaboração do sistema de medição compreende da eleição, a partir das definições de visão, missão e estratégia da empresa, de uma relação de objetivos estratégicos, seus indicadores de monitoramento, suas metas de superação e as iniciativas correspondentes para o seu alcance.

Uma das mais importantes características do BSC é focar uma quantidade limitada de métricas, que melhoram o foco, a gerência e o agrupamento de métricas 
similares em grupos denominados de perspectivas financeiras, dos clientes, dos processos e de aprendizado e crescimento organizacional (Figura 5).

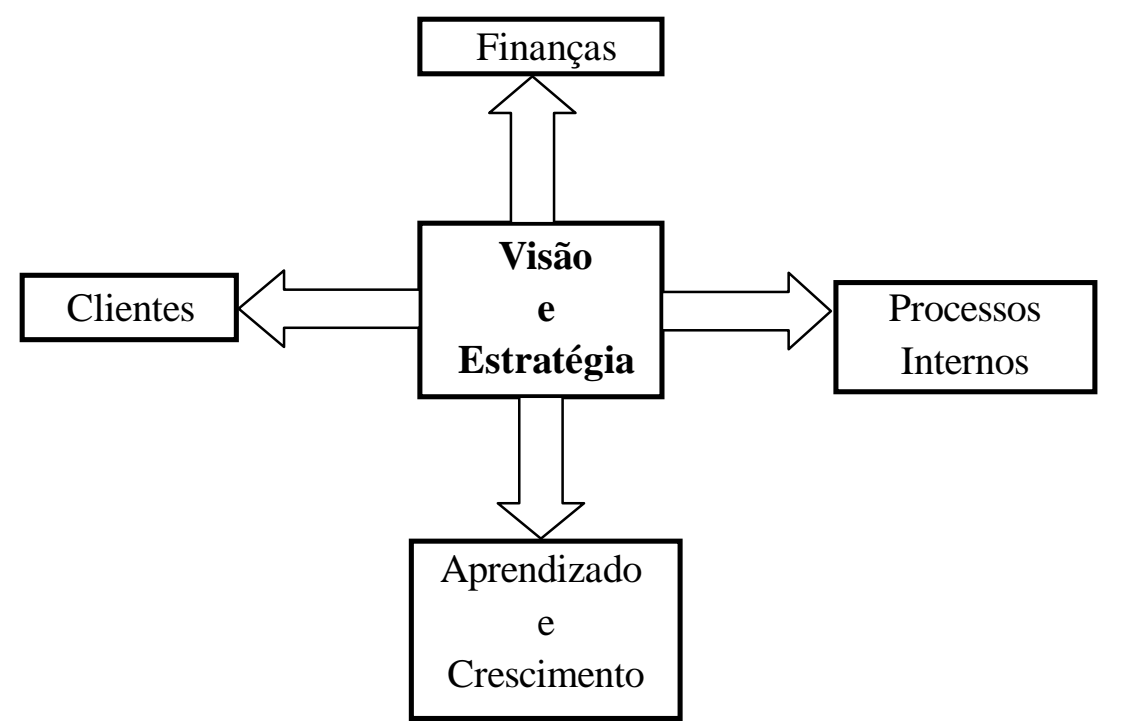

Figura 5 - As quatro perspectivas do Balanced Scorecard (Kaplan \& Norton, 1997)

Pinto (2002) avaliou um conjunto proposto de indicadores analítico-descritivos e de medição de desempenho para frotas de agroindústrias canavieiras brasileiras. O autor por meio de um questionário aplicado a 323 usinas de açúcar e álcool nas safras 1997/1998 e 1999/2000, conseguiu efetivar os indicadores sugeridos como ferramenta para o gerenciamento de frotas canavieiras, dentre outros resultados obtidos.

Takashina \& Flores (1996) apresentam um método para a gestão de indicadores, mostrado na Figura 6. Os autores sintetizaram a proposta em cinco fases para um melhor delineamento do método, descritas a seguir. 


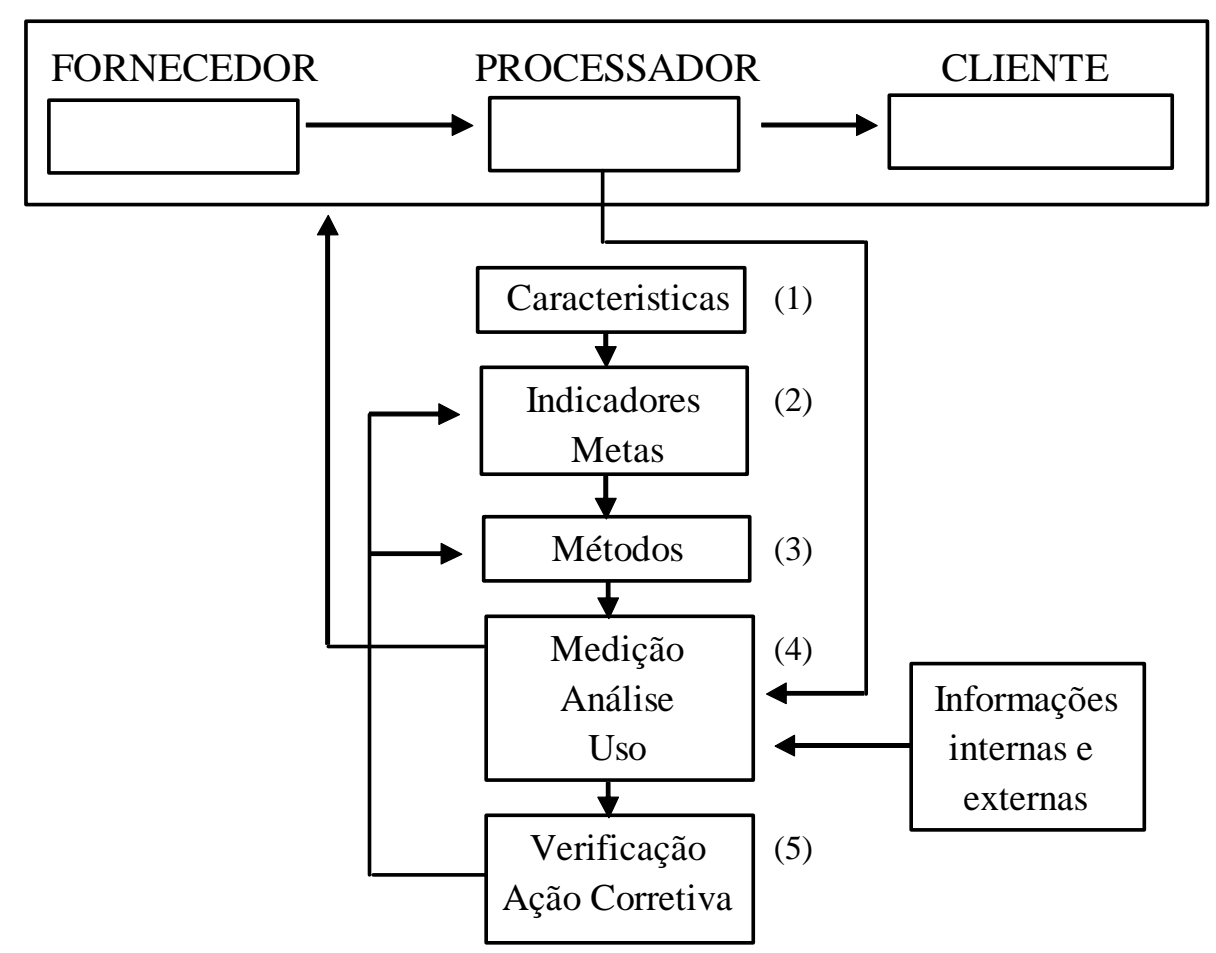

Figura 6 - Gestão de indicadores e sua relação com o processo, Takashina \& Flores (1996)

A primeira fase (1), denominada de definição das características do produto e do processo, deve-se identificar o(s) processo(s) de maior relevância para a empresa, a razão da sua existência, e descrever suas entradas e saídas. A segunda fase (2) destina-se a criar os indicadores e metas focando o objetivo de cada processo identificado na primeira fase. Após a determinação dos indicadores, na terceira fase (3) define-se o método para medir e interpretar o desempenho dos mesmos, tendo o cuidado para não interferir e nem alterar o processo. A quarta fase (4) denominada de medição, análise e uso dos dados e resultados, consiste em coletar os dados e transformá-los em informação para a tomada de decisão. Já na ultima fase (5), é realizada a verificação da eficácia do processo e, quando necessário, desenvolve-se ações corretivas para aprimorá-los. 


\subsection{Processos de semeadura}

As técnicas de revolvimento do solo (aração e gradagem) que são utilizadas pelos agricultores brasileiros, em sua maioria, são frutos da transposição para os trópicos de sistemas de produção desenvolvidos para regiões de clima frio. Segundo Primavesi (1980), nos países de clima temperado, a exposição do solo desnudo ao sol e à chuva cumpre um papel importante no seu reaquecimento após o degelo no início da primavera, processo necessário para acelerar a reativação de sua microvida. Nas regiões tropicais, permanentemente quentes, isso não é necessário. Pelo contrário, o sol e as chuvas torrenciais, características da região, tornam necessário evitar a exposição do solo desnudo ao tempo. O sol forte tem um efeito devastador sobre a microvida nas camadas mais superficiais do solo e as chuvas torrenciais carreiam enormes quantidades e solo desestruturado e pulverizado.

Essa degradação progressiva nos recursos naturais, provocadas por práticas convencionais de preparo do solo, obriga o agricultor a recorrer cada vez mais a técnicas mecânicas e químicas, no sentido de manter as condições favoráveis ao desenvolvimento das culturas, na medida em que elas próprias contribuem para agravar a situação (Borges Filho, 2001). Juntando-se a essas degradações praticadas, a monocultura existente no Brasil, provocam um intenso processo de degradação ambiental, especialmente no solo e na água, fazendo a compactação do solo e a erosão, um dos mais importantes problemas ambientais decorrentes da intensa mecanização (Plantio Direto, 1999).

O preparo do solo feito por sistemas convencionais pode atuar nas propriedades químicas do solo, seja diretamente, alterando a distribuição do teor de nutriente no solo, e conseqüentemente a disponibilidade para as plantas, ou indiretamente, por meio das alterações na estrutura do solo, modificando o balanço hídrico e a atividade biológica (Borges, 2003).

Diante da necessidade de manter o solo protegido, surge uma nova técnica de manejo do solo que leva em conta os imperativos ecológicos das regiões tropicais, o plantio direto na palha - PDP, agora mais recentemente chamado de semeadura direta. Esse sistema de produção foi introduzido na região Sul do país no início da década de setenta como uma alternativa para se controlar a erosão. Consiste em um sistema de 
exploração agrícola onde não há o revolvimento da superfície por implementos e a cobertura vegetal e/ou restos culturais são mantidos sobre o solo, dispensando o tradicional preparo com as operações de aração e gradagem (Landers, 1998).

A manutenção dos resíduos culturais na superfície do solo propicia as condições necessárias para que o micro e a mesovida passem a atuar, produzindo, como resultado, um solo estruturado e pronto para ser semeado. Trata-se, portanto, de uma substituição de procedimentos mecânicos por processos biológicos naturais (Romeiro, 1998).

Segundo a Federação Brasileira de Plantio Direto (FEBRAPDP, 2005) estima-se que hoje aproximadamente 22 milhões de hectares do território brasileiro são cultivados sobe o sistema de semeadura direta, com elevada expansão principalmente no cerrado (São Paulo, Mato Grosso do Sul, Mato Grosso e Goiás) com o cultivo de milho e algodão.

Na região dos Cerrados, o sistema foi introduzido no início dos anos 80, mas a sua adoção mais intensa por parte dos produtores ocorreu somente a partir da década de 90, motivada principalmente pelas vantagens econômicas, menor custo de produção. A transposição do sistema de semeadura direta da região Sul para os Cerrados apresentou uma série de dificuldades, devido principalmente às condições climáticas. O inverno seco e relativamente quente da região não permitia o desenvolvimento das culturas de inverno utilizadas na região Sul, que apresenta invernos frios e chuvosos. Essa diferença climática exigiu mudanças fundamentais nas técnicas empregadas no Sul do Brasil, o que levaria ao desenvolvimento de tecnologia própria para a região (Borges Filho, 2001).

Como principais benefícios físicos, químicos e biológicos da adoção do sistema de semeadura direta, podem ser citados de acordo com Siqueira Neto (2003): a diminuição do escoamento superficial e erosão; elevação do metabolismo respiratório dos microrganismos e das raízes; aumento do teor de matéria orgânica; manutenção da temperatura e umidade do solo. Complementando, Landers (2005) acrescenta a estratificação da camada superficial do solo por meio do acúmulo acentuado de matéria orgânica e nutriente, e a redução nas operações mecanizadas de preparo do terreno.

O efeito da semeadura direta sobre a produtividade das culturas depende do local, 
das condições de clima e solo e do tempo de implantação, ocorrendo grandes variações entre os resultados de pesquisas. Cruz (1999) afirma que o maior ou menor efeito direto sobre o desenvolvimento e a produtividade da cultura depende da adequação de sua implementação.

\subsubsection{Máquinas para a semeadura direta}

A produção de grãos, fundamentada em sistemas sustentáveis, requer o desenvolvimento de equipamentos agrícolas cada vez mais eficientes e precisos. As semeadoras representam importante elemento nesse contexto, uma vez que, o desenvolvimento de uma cultura bem como sua produção depende da execução correta da operação no campo.

Coelho (1996) define uma máquina para semeadura como aquela destinada a dosar certa quantidade de semente e lançá-las no solo de acordo com certo padrão de distribuição. Semeadora é a designação dada às máquinas que tem por determinado fim colocar no solo os grãos utilizados para a instalação de culturas, ou seja, as sementes. O termo semeadora-adubadora é utilizado para aquelas máquinas que tem por função dosar e colocar no solo semente e fertilizante, numa mesma operação, com a necessidade destes insumos serem depositados em profundidades corretas, fazendo o fechamento do sulco e compactação adequados.

As semeadoras-adubadoras são essencialmente constituídas de mecanismos dosadores de sementes e fertilizantes, sulcadores, controladores de profundidade, cobridores de sementes e rodas compactadoras (Pacheco, 1994).

Gadanha Júnior et al. (1991), afirmam que a semeadora-adubadora para o sistema de semeadura direta é constituída de maneira semelhante às semeadoras-adubadoras convencionais, tanto as de precisão como as de fluxo contínuo, mas, possui algumas modificações que permitem a ela trabalhar em solos não preparados e com cobertura vegetal. De acordo com esses autores, uma modificação é a introdução de um sistema de corte, colocado à frente da máquina, que realiza o corte da cobertura vegetal abrindo caminho para o sulcador, ou funcionando como o próprio. Um sistema de articulação das rodas é outra mudança em relação às semeadoras-adubadoras convencionais, o qual 
permite o acompanhamento das irregularidades do terreno, de modo a não alterar a distribuição da semente e fertilizante. Os reservatórios são maiores, e também podem realizar semeadura convencional ou cultivo mínimo. Alguns modelos possuem um compartimento onde podem ser colocados contrapesos que melhoram o desempenho da máquina em terrenos com dificuldade de penetração.

De acordo com Landers (1995) o sistema de semeadura direta exige que as semeadoras-adubadoras sejam: versáteis (para servirem a diferentes culturas e espaçamentos distintos), resistentes (para agüentarem maiores pressões, sem desgaste ou empenamento), que abram o sulco com pouca pressão de terra e palha, cubram e tirem o ar do sulco da semente, que não embuchem com palha e terra, tenham boa penetração e controle de profundidade, coloquem as sementes em uma profundidade constante e adequada e em contato com o solo e não envolvida na palha, e depositem o adubo na profundidade e distância ótima em relação à semente. Saturnino \& Landers (1997) citam que pequenos produtores podem fazer a semeadura direta com técnicas de cultivo manual por meio de “matracas” adaptadas e também o uso de semeadoras de tração animal.

Alguns fatores que afetam a semeadura são descritos por Balastreire (1990) e Ortiz-Cañavate (1995) e devem ser monitorados durante o processo. Os autores citam que a eficiência da semeadura pode estar relacionada com a semente, o solo, a máquina, o clima e o operador. As sementes influenciam a semeadura pela quantidade de sementes a ser distribuída, pela sua viabilidade, sua uniformidade de tamanho e distribuição, sua forma, profundidade de colocação e tratamento com defensivos e inoculantes. O solo pode influenciar pelo seu preparo, fertilidade e textura, além de fatores ligados ao clima como teor de umidade, temperatura e aeração. O operador é um fator importante na eficiência da semeadura pela sua capacidade em regular a máquina, manter a velocidade adequada de operação, o espaçamento adequado entre as linhas de semeio e manter a máquina em condições de uso satisfatória, com manutenções e reparos corretos.

Em função dos diversos fatores que interferem na operação de semeadura, afetando o estabelecimento e a produtividade da cultura, Silva et al. (2000) destacam a 
necessidade de monitoramento do processo por indicadores operacionais.

\subsubsection{Avaliação do processo de semeadura}

Kurachi et al. (1986) relataram que as semeadoras-adubadoras de diferentes tipos e modelos existentes no mercado brasileiro devem ter sua eficiência avaliada por meio de dois indicadores principais com relação à distribuição longitudinal de sementes, sendo eles a porcentagem de espaçamentos aceitáveis e o coeficiente de variação geral da produção de espaçamentos. Segundo o autor, estudos apontaram a uniformidade de distribuição longitudinal de sementes como uma das características que mais contribuem para um estande adequado de plantas e, conseqüentemente, para a melhoria da produtividade das culturas. Estudos realizados por Delafosse (1986), Vieira Junior (1999), Dourado Neto et al. (2001) e Palhares (2003), mostraram que a falta de regularidade de espaçamento entre plantas pode resultar em perdas significativas na cultura do milho.

Righes et al. (1990) fizeram a avaliação dos efeitos agronômicos da semeadura direta na cultura do milho realizado por diferentes semeadoras. Os autores avaliaram os seguintes indicadores: resistência do solo a penetração dos diferentes mecanismos sulcadores, por meio de um penetrógrafo mecânico equipado com um cone de 0,2 polegadas quadradas de área frontal, conforme norma ASAE S313.2 (ASAE, 1990); absorção de água pela semente em função da acomodação do solo junto a ela; volume de solo mobilizado; profundidade da semeadura; demanda energética das semeadoras e velocidade de emergência de plantas. Todos os indicadores avaliados no trabalho sofreram forte influência da velocidade de deslocamento do conjunto trator-semeadora, e foi determinado que os mecanismos das semeadoras necessitavam de melhorias estruturais.

Na avaliação de nove semeadoras-adubadoras de milho, realizada por Mantovani et al. (1992), nos campos experimentais do Centro Nacional de Pesquisa de Milho e Sorgo - CNPMS, em Sete Lagoas, MG. Foram utilizados os indicadores de precisão de semeadura (porcentagem de espaçamentos normais); estande (número de plantas por hectare); distribuição de fertilizante (quilos por hectare) e controle de profundidade de 
semeadura. Os autores verificaram que todos os indicadores avaliados apresentaram desempenho diferenciado. O espaçamento médio entre as sementes variou entre 16,5 e 23,6 centímetros, o estande de plantas entre 35 e 55 mil plantas por hectare, fertilizante entre 141 a 230 kilos por hectare, e a profundidade no intervalo de 4,2 a 8,2 centímetros, concluindo que as semeadoras foram sensíveis ao aumento da velocidade de deslocamento quanto à uniformidade de distribuição de sementes e fertilizante e, apresentaram bons desempenhos, quanto ao controle de profundidade, qualidade das sementes e demanda de potência.

Estudando a eficiência do processo operacional de semeadura direta de milho, Peche Filho (1999) apresenta uma metodologia desenvolvida pelo Centro de Mecanização e Automação do Instituto Agronômico de Campinas - IAC, que avalia por meio das variáveis: sementes por metro, profundidade e espaçamento longitudinal das sementes e distância entre linhas da semeadura; a qualidade operacional em relação a parâmetros considerados ideais agronomicamente. A proposta metodológica mostrou-se eficiente na obtenção de valores, mas o autor reforça a necessidade de estudos para o aprimoramento do trabalho.

Reis (2000) estudou a inter-relação solo-semente com duas semeadorasadubadoras de semeadura direta, em diferentes umidades de um solo argiloso. No estudo o autor avaliou alguns parâmetros indicadores do desempenho do conjunto trator semeadora, dentre eles a resistência do solo à penetração, conforme norma ASAE S313.2 (ASAE, 1990); velocidade de emergência de plantas; consumo horário de combustível por meio de um fluxômetro e a patinagem do rodado motriz do trator, descrita pela norma ASAE EP496 (1990). O autor concluiu que a umidade influenciou a germinação das sementes e a patinagem do conjunto, e não apresentou efeitos significativos para o consumo de combustível.

No estudo do desempenho de uma semeadora-adubadora no estabelecimento e na produtividade da cultura do milho sob plantio direto, Silva et al. (2000) avaliaram a densidade de semeadura, profundidade da semente e adubo, percentual de espaçamentos entre sementes, estande final de plantas, massa de grãos, produção de espigas e produtividade do milho operando em quatro velocidades de deslocamento e em duas 
profundidades de adubação. O aumento da velocidade reduziu o número de sementes e a uniformidade dos espaçamentos na linha de semeadura do milho. Com menor velocidade e adubação realizada na profundidade maior, as semeadoras propiciaram melhores estandes de plantas e número de espigas por metro, que trouxe um rendimento maior de grãos.

Oliveira et al. (2000) analisaram o desempenho de uma semeadora-adubadora para plantio direto. Os autores realizaram os estudos variando além da velocidade de deslocamento, o tipo de solo e a cobertura vegetal. No trabalho foram avaliados: a patinagem do trator e da semeadora-adubadora, o consumo de combustível e a potência exigida, a distribuição de fertilizante e o nível de danos às sementes. Depois da semeadura, foram avaliados o número de sementes distribuídas, o estande final, a profundidade de plantio e a distribuição longitudinal da semente. A semeadoraadubadora apresentou índices de patinagem aceitável para o rodado; valores de potência demandados inferiores aos indicados pelo fabricante, nas condições de solo e cobertura vegetal; boa regularidade na distribuição transversal e longitudinal de sementes; profundidade média de plantio bem próximo ao previsto pela regulagem.

Com a finalidade de fornecer subsídio para o aperfeiçoamento de uma semeadora-adubadora de plantio direto, nas operações em solos argilosos e de origem basáltica no estado do Paraná, Casão Junior et al. (2000) estudaram a demanda energética e o desempenho operacional da máquina no campo. Foi observado que o esforço de tração variou em função da umidade e características mecânicas do solo, atingindo valores elevados, o que exigiu, em situações extremas, um trator com potência elevada, pouco disponível nas propriedades agrícolas dos solos basálticos do Paraná. As características gerais avaliadas no desempenho da semeadora-adubadora mostraram a capacidade para atuar na realização do plantio direto no basalto paranaense, embora os autores consideraram que vários aspectos podem ser melhorados.

Acosta \& Molin (2001) avaliaram três protótipos de semeadoras rotativas de covas para semeadura direta de milho em ensaios de laboratório e de campo, submetidos a diferentes velocidades. Os resultados mostraram que as semeadoras sofreram influência da velocidade de deslocamento e do mecanismo dosador. 
Suguisawa et al. (2003) avaliaram a qualidade da semeadura mecanizada da cultura do milho sobre sistema de plantio direto, a fim de verificar sua conformidade com os padrões agronômicos estabelecidos e detectar oscilações na operação. Foram estabelecidos sete indicadores: número de sementes por metro linear, espaçamento entre sementes e passadas da semeadora, profundidade de semente e do adubo, número de sementes encestadas e descobertas. Os resultados demonstraram que a operação não se encontrava em conformidade com os padrões agronômicos adequados ao desenvolvimento ideal da cultura. Os autores salientaram que as unidades da semeadora comportaram-se como máquinas distintas e, portanto, devem ser analisadas de forma individual.

Na avaliação da demanda energética e eficiência da distribuição de sementes de uma semeadora-adubadora para semeadura direta, Mahl et al. (2004) utilizaram como indicadores: força de tração, potência na barra de tração, consumo de combustível, capacidade de campo efetiva, distribuição longitudinal de plantas, coeficiente de variação, índice de precisão e estande de plantas. Os autores submeteram a máquina à variação de velocidade e condições de solo. Concluiu-se que o aumento da velocidade aumentou a capacidade operacional da semeadora, porém, reduziu o porcentual de espaçamentos normais e, conseqüentemente, elevou o porcentual de espaçamentos múltiplos de falhos.

Os fatores ambientais devem ser monitorados, segundo Silva \& Daniel (2004), pois podem influenciar negativamente no desempenho dos mecanismos de ataque ao solo das semeadoras e, como conseqüência comprometer a qualidade da distribuição de sementes ao longo do sulco de semeadura, uniformidade na profundidade de deposição da semente e do fertilizante e prejudicar a formação de um estande ideal. Outro fator de importância citado é a variação na velocidade de deslocamento da operação, pois pode reduzir em até $10 \%$ a população final de plantas, no caso dos mecanismos dosadores. 


\section{MATERIAL E MÉTODOS}

O método utilizado foi uma adaptação de Takashina \& Flores (1996). Os autores adotaram seis etapas distintas para a gestão dos indicadores, com base nessas etapas o método adaptado está representado na Figura 7.

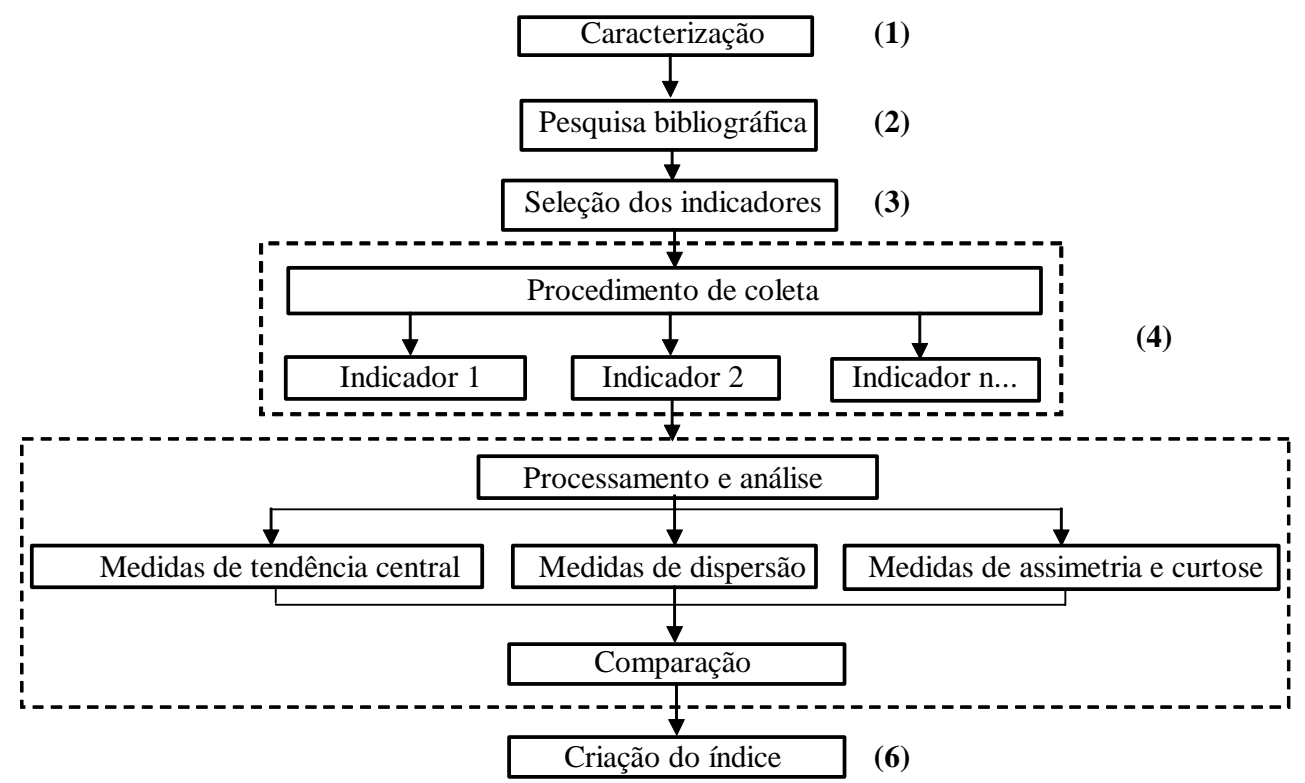

(5)

Figura 7 - Fluxograma da metodologia adaptada

Como é possível observar na Figura 7, a primeira etapa (1)*, denominada caracterização, constituiu-se em descrever os processos de produção utilizados pela empresa agrícola. A propriedade onde foi realizado o estudo localiza-se no estado do Paraná, município de Piraí do Sul, nas coordenadas 24²0’46’'S de latitude e 5008’06”, W de longitude e altitude média de 950 metros acima do nível do mar. Ela possui uma área total de 4090 ha, sendo 3100 ha plantados, divididas em 24 talhões. A

\footnotetext{
* Os números entre parênteses referem-se à Figura 7.
} 
região possui clima do tipo Cfb (clima subtropical úmido mesotérmico), segundo a classificação de Koppen, com verões frescos e ocorrências freqüentes de geadas, sem estação seca, com temperatura média anual entre 17 e $18^{\circ} \mathrm{C}$, e precipitação pluviométrica média anual de $1750 \mathrm{~mm}$. O relevo é suave ondulado, com solo classificado como Latossolo Vermelho Escuro, e sistema de produção vigente contemplando as culturas do milho e soja no verão, trigo e aveia no inverno, todas sob o sistema de semeadura direta. As características das máquinas e dos insumos utilizados na propriedade para o processo de semeadura encontram-se no anexo A.

Na segunda etapa (2), denominada de pesquisa bibliográfica, realizou-se uma busca na bibliografia com relação a trabalhos sobre o processo de semeadura, identificando-se os indicadores utilizados na avaliação desse processo. Em seguida os indicadores foram classificados e ordenados em grupos, com as referências de onde foram obtidos.

Na terceira etapa (3) efetuou-se a seleção dos indicadores. Para tanto, realizaramse discussões com o corpo técnico da empresa, para selecionar os indicadores propostos pela bibliografia, bem como os limites aceitáveis para cada um deste. Os valores estabelecidos são baseados em critérios agronômicos. Esses limites foram divididos em inferior (Limite Inferior Especificado - LIE) e superior (Limite Superior Especificado LSE), criando-se uma faixa aceitável para cada indicador utilizado. Levou-se em conta na seleção, a importância agronômica e a aplicação prática do indicador, considerandose fatores como: tempo e custo do material para a coleta, disponibilidade e limitações dos funcionários.

Uma vez selecionados os indicadores, a quarta etapa (4) correspondeu à determinação do método para a coleta dos dados a campo. O princípio básico utilizado para a definição do método foi à avaliação constante do processo sem a interrupção do mesmo. Foram observados para cada indicador: tamanho da amostra, quantidade de repetições, local, material, formas de identificação e contagem. Para a coleta desses indicadores, desenvolveram-se procedimentos operacionais - PO.

Com os dados coletados iniciou-se a quinta etapa (5), onde se faz a análise dos dados com base na estatística descritiva. Os parâmetros considerados foram os de 
medidas de tendência central (média, mediana e moda), por serem utilizados para indicar um valor que tende a tipificar, ou a representar melhor um conjunto de números; medidas de dispersão (amplitude, desvio padrão e coeficiente de variação) que indicam se os valores estão relativamente próximos uns dos outros ou separados; medidas de assimetria e curtose (coeficiente de assimetria e curtose), além da distribuição de freqüência e percentual retratada na forma gráfica. Após a análise dos dados pela estatística descritiva realizou-se a comparação, utilizando-se os limites previamente determinados e os encontrados no campo.

Na sexta etapa (6) desenvolveu-se um índice adaptado do método proposto por Dodson (1998), que utiliza o conceito de valores relativos. Para cada indicador selecionado foi criado um índice denominado de Índice do Indicador - Iind, apresentado na equação 01. Ele tem como finalidade realizar um comparativo entre o que ficou dentro dos limites especificados e o que era desejado para o processo, tendo como referencial teórico ideal o valor 1,0.

$$
\text { Iind }=\frac{P O I}{P D I}
$$

onde,

Iind = índice do indicador

$P O I=$ porcentagem obtida pelo indicador dentro dos limites especificados

$P D I=$ porcentagem desejada para o indicador dentro dos limites especificados

O corpo técnico da empresa determinou que $100 \%$ dos valores dos indicadores coletados $(P D I)$ deveriam estar dentro dos limites especificados para o processo. Com os índices dos indicadores, foi determinado o Índice de Qualidade do Processo - IQP, calculado de acordo como a equação 02. 


$$
I Q P=\frac{1}{n} \sum_{i=1}^{n} \text { Iind }
$$

onde,

$I Q P$ = índice de qualidade do processo

$n=$ número de indicadores utilizados

Iind = índice do indicador

O IQP foi criado para determinar a qualidade do processo de semeadura de uma forma global, relacionando todos os indicadores envolvidos no processo. Por meio dele obteve-se um quadro resumido das variações ocorridas durante a execução das atividades. 


\section{RESULTADOS E DISCUSSÃO}

Neste capítulo são apresentadas as etapas para a gestão dos indicadores na propriedade onde se realizou o estudo, e as informações disponibilizadas para a empresa.

\subsection{Caracterização do sistema de produção}

Foi identificado o processo para obtenção de grãos como sendo o de maior relevância para a empresa. Os técnicos apresentaram o fluxograma das operações mecanizadas realizadas na propriedade ao longo do ano agrícola para produção no sistema de semeadura direta (Figura 8).

INVERNO

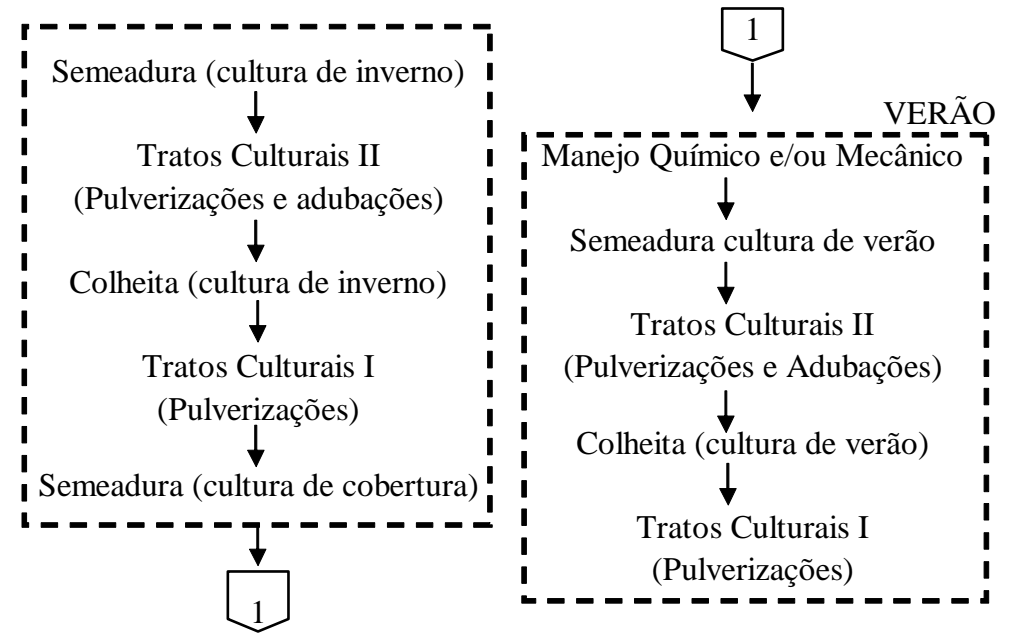

Figura 8 - Operações mecanizadas para produção de grãos na propriedade durante o ano agrícola

Na Figura 8 as operações mecanizadas apresentadas foram divididas em dois ciclos. O primeiro denominado de inverno, onde são realizadas: a semeadura da aveia e trigo, pulverizações pré e pós-emergentes, adubações de cobertura e colheita. O 
segundo, chamado de verão, com as seguintes operações: manejo químico e mecânico da cultura de cobertura, semeadura do milho e soja, pulverizações pré e pós-emergentes, adubações de cobertura e colheita.

\subsection{Pesquisa Bibliográfica}

Com a pesquisa realizada foram identificados os indicadores para o processo de semeadura mecanizada e com a análise desses foi possível dividir o grupo em três classes. A primeira classe (1), denominada de desempenho das máquinas, avalia o processo por meio da atuação das máquinas. A segunda (2), qualidade da operação determina as características do produto conforme as recomendações agronômicas. A terceira (3) demonstra o desenvolvimento das plantas após a semeadura.

Na Tabela 2 são apresentados os indicadores encontrados para a operação de semeadura onde, o nome do indicador é colocado na primeira coluna e o(s) autor(es) citados na segunda. Alguns dos indicadores foram citados por mais de um autor, o que caracteriza uma visão compartilhada pelos pesquisadores da área.

Observa-se na Tabela 2 que dos vinte e cinco indicadores obtidos, sete foram classificados como referentes ao desempenho da máquina (1), doze para a qualidade da operação (2) e seis no tocante ao desenvolvimento das plantas (3), o que equivale a dizer que existe uma preocupação maior na forma como o processo está sendo executado no campo. O número de referências bibliográficas referenciadas no total para os indicadores foi de dezessete trabalhos, $65 \%$ dos quais relativos ao desempenho das máquinas, $88 \%$ para a qualidade da operação e $47 \%$ referentes ao desenvolvimento das plantas. Nota-se que uma mesma referência bibliográfica pode apresentar mais de um indicador para classes diferentes. 
Tabela 2. Indicadores identificados na pesquisa bibliográfica e ordenados em classes de uso para o processo de semeadura

\begin{tabular}{|c|c|c|}
\hline CLASSE & INDICADOR & AUTOR * \\
\hline \multirow{7}{*}{$\begin{array}{l}1 \text { - Desempenho das } \\
\text { máquinas }\end{array}$} & 1. Consumo de combustível & $11 ; 14$ \\
\hline & 1. Corte da cobertura vegetal & 3 \\
\hline & 1. Demanda energética & $2 ; 3 ; 4 ; 9 ; 11 ; 15$ \\
\hline & 1. Desempenho operacional & $2 ; 4$ \\
\hline & 1. Ocorrência de "embuchamento" & $2 ; 3 ; 16$ \\
\hline & 1. Patinagem do conjunto & $4 ; 11 ; 13 ; 16$ \\
\hline & 1. Velocidade de deslocamento & $2 ; 5 ; 8 ; 13 ; 15 ; 16$ \\
\hline \multirow[t]{12}{*}{$\begin{array}{l}2 \text { - Qualidade da } \\
\text { operação }\end{array}$} & $\begin{array}{l}\text { 2. Aterramento e cobertura do sulco com } \\
\text { palha }\end{array}$ & $2 ; 3 ; 4 ; 5 ;$ \\
\hline & 2. Densidade de semeadura & $2 ; 12 ; 13$ \\
\hline & 2. Distância entre plantas & $\begin{array}{l}1 ; 5 ; 6 ; 10 ; 11 ; 14 ; \\
15 ; 16\end{array}$ \\
\hline & 2. Distância entre semente e fertilizante & $2 ; 4 ; 17$ \\
\hline & 2. Distância entre sementes no sulco & $7 ; 12 ; 13$ \\
\hline & 2. Distribuição transversal de fertilizante & $2 ; 3 ; 10 ; 11$ \\
\hline & 2. Distribuição transversal de semente & $2 ; 3 ; 4$ \\
\hline & 2. Profundidade da semente & $\begin{array}{l}2 ; 3 ; 4 ; 5 ; 10 ; 11 ; \\
12 ; 13 ; 15 ; 16 ; 17\end{array}$ \\
\hline & 2. Profundidade do fertilizante & $2 ; 3 ; 5 ; 16$ \\
\hline & 2. Sementes entre palha & 17 \\
\hline & 2. Sementes expostas & $2 ; 3 ; 17$ \\
\hline & 2. Solo mobilizado & $3 ; 14 ; 16$ \\
\hline \multirow{6}{*}{$\begin{array}{l}3 \text { - Desenvolvimento } \\
\text { da Planta }\end{array}$} & 3. Absorção de água pela semente & 15 \\
\hline & 3. Danificação das sementes & $4 ; 11 ; 16$ \\
\hline & 3. Emergência de plantas & $2 ; 3 ; 4 ; 15$ \\
\hline & 3. Qualidade fisiológica da semente & $4 ; 5$ \\
\hline & 3. Resistência à penetração & $14 ; 15$ \\
\hline & 3. Uniformidade da semente & $3 ; 4 ; 16$ \\
\hline
\end{tabular}


Após a pesquisa e análise dos indicadores para a operação de semeadura (Tabela 2) partiu-se para a terceira etapa de gestão dos indicadores para o processo, onde se realizou a seleção dos indicadores encontrados.

\subsection{Seleção dos indicadores}

De posse de todos os indicadores levantados na etapa 2 pela pesquisa realizada na bibliografia, verificou-se a impossibilidade da avaliação de todos, pela necessidade de envolver um grande número de pessoas, da grande quantidade de tempo para coleta de campo e os custos elevados para sua implementação. Após as reuniões com o corpo técnico foram selecionados nove indicadores, que são apresentados na Tabela 3.

Tabela 3. Indicadores selecionados para a coleta de campo

\begin{tabular}{|c|c|c|}
\hline INDICADOR & UNIDADE & TIPO \\
\hline Densidade de semeadura & sementes.m $^{-1}$ & \multirow{9}{*}{ 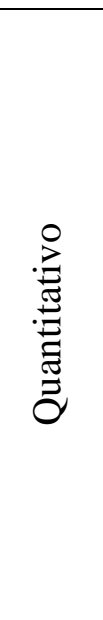 } \\
\hline Distância entre semente e fertilizante & $\mathrm{cm}$ & \\
\hline Distância entre sementes no sulco & $\mathrm{cm}$ & \\
\hline Emergência de plantas & plantas. $\mathrm{m}^{-1}$ & \\
\hline Profundidade da semente & $\mathrm{cm}$ & \\
\hline Profundidade do fertilizante & $\mathrm{cm}$ & \\
\hline Semente entre palha & $\%$ & \\
\hline Semente exposta & $\%$ & \\
\hline Solo mobilizado & $\mathrm{cm}$ & \\
\hline
\end{tabular}

Dos indicadores selecionados na Tabela 3, oito deles trazem informações referentes à qualidade da operação de semeadura, e um diz respeito ao desenvolvimento das plantas. A distribuição espacial das sementes no solo foi representada pelos indicadores de densidade de semeadura, distância entre sementes no sulco e profundidade das sementes. A distância entre a semente e o fertilizante e a profundidade do fertilizante mostram o posicionamento do adubo no processo de semeadura. As sementes entre palha e expostas indicam aquelas que ficaram para fora do sulco de 
semeadura, enquanto que o solo mobilizado implica em abertura da palhada na linha semeada. A emergência de plantas aponta o número de plântulas emergida no campo.

\subsection{Definição do método de coleta}

Para a coleta dos indicadores que foram selecionados na etapa 3, utilizaram-se os procedimentos operacionais (PO) criados, estando os mesmos apresentados e descritos no anexo B. Os procedimentos foram executados por técnicos agrícolas da propriedade, treinados e acompanhados por um agrônomo durante o processo.

\subsection{Análise e comparação}

Os valores dos limites de especificação para o processo de semeadura neste caso são apresentados pela empresa na Tabela 4, e são fundamentados em critérios agronômicos adotados para a cultura do milho.

Tabela 4. Limites de especificação utilizados pela propriedade para o processo

\begin{tabular}{lcc}
\hline Indicador & \multicolumn{2}{c}{ Limites de Especificação } \\
Inferior & Superior \\
\hline Densidade de semeadura (sementes.m ${ }^{-1}$ ) & 5,3 & 6,3 \\
Distância entre semente e fertilizante (cm) & 4,0 & 6,0 \\
Distância entre sementes no sulco (cm) & 15,2 & 20,6 \\
Emergência de plantas (\%) & 95 & 100 \\
Profundidade da semente (cm) & 3,0 & 4,0 \\
Profundidade do fertilizante (cm) & 8,0 & 9,0 \\
Semente entre palha (sementes) & 0,0 & 0,0 \\
Semente exposta (sementes) & 0,0 & 0,0 \\
Solo mobilizado (cm) & $*$ & $*$ \\
\hline
\end{tabular}

* dado não especificado na bibliografia para operação de semeadura

Para os indicadores de semente entre palha e exposta, não foram encontradas recomendações agronômicas que pudessem ser adotadas como limites, tendo sido necessário a determinação destes valores pelo corpo técnico da empresa. 


\subsubsection{Densidade de semeadura}

É possível observar na Tabela 5 que o indicador densidade de semeadura apresenta regularidade na distribuição dos dados, existindo considerável proximidade entre os valores da média, mediana e moda indicando uma tendência dos dados estarem em torno da média. Este critério é reforçado pelos valores do coeficiente de variação e desvio padrão baixo, o que demonstra que as semeadoras apresentaram uma regularidade na distribuição de sementes no sulco de semeadura, comportamento esperado durante a operação, visando a diminuição das falhas nas linhas de semeadura e aumento da uniformidade da cultura.

Tabela 5. Resultado da análise da estatística descritiva para o indicador densidade de semeadura

\begin{tabular}{cc}
\hline Descrição & Valor (sementes.m $\mathbf{~}^{\mathbf{1}}$ ) \\
\hline Média & 5,55 \\
Mediana & 5,67 \\
Moda & 5,67 \\
Desvio padrão & 0,45 \\
CV\% & 8,13 \\
Curtose & $-0,41$ \\
Assimetria & 0,02 \\
Amplitude & 2,33 \\
Mínimo & 4,33 \\
Máximo & 6,67 \\
Número de amostras & 269 \\
\hline
\end{tabular}

O histograma de distribuição dos dados apresentado na Figura 9 para o indicador densidade de semeadura demonstra que os dados encontram-se em torno da média, o que revela uma curva levemente platicúrtica, dizendo que a curva de frequência apresenta uma distribuição mais plana (ou mais achatada em sua parte superior). A curva normal pode ser considerada simétrica pelos valores encontrados nas medidas de tendência central (média, mediana e moda), característica desejável nas operações agrícolas mecanizadas por não apresentar uma tendência dos dados estarem nos extremos da curva. 


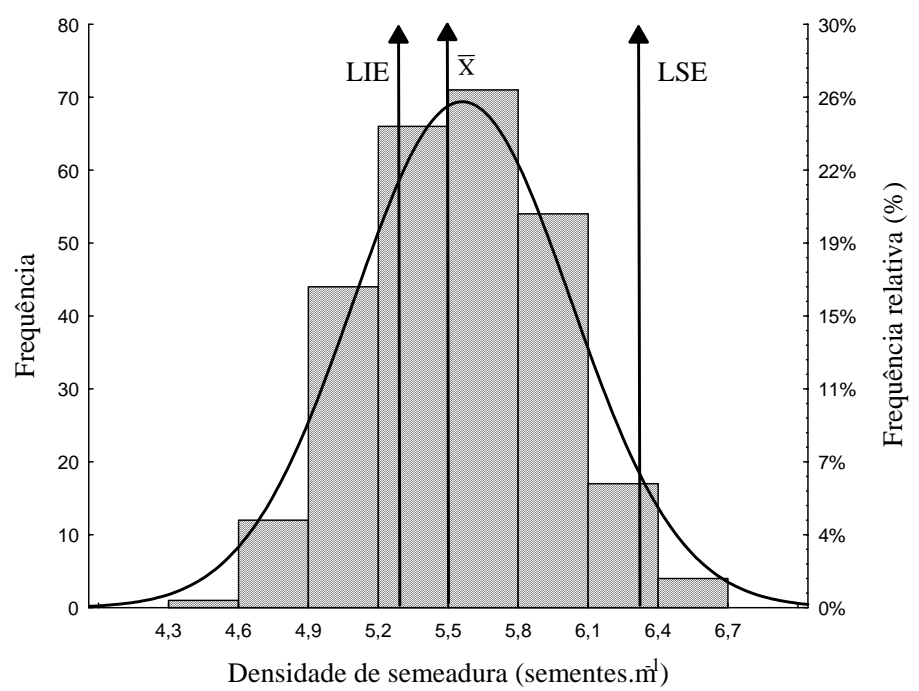

Figura 9 - Histograma de distribuição e curva normal dos dados do indicador de densidade de semeadura

Observa-se na Figura 9 que 77\% dos dados do indicador densidade de semeadura ficaram dentro dos limites especificados para o processo, sendo que o restante dividiu-se com 21\% abaixo do LIE e 2\% acima do LSE. Este comportamento demonstrou que as semeadoras apresentaram uma tendência em depositar menos sementes por metro de sulco semeado, mostrando que o processo necessita de melhorias na distribuição de sementes no sulco.

A Figura 10 mostra a relação entre a densidade de semeadura obtida pelas semeadoras e a desejada na regulagem da máquina. A densidade de semeadura considerada na regulagem das semeadoras $\left(5,6\right.$ sementes. $\left.\mathrm{m}^{-1}\right)$ está dentro dos limites especificados para o processo, e o valor obtido $\left(5,5\right.$ sementes. $\left.\mathrm{m}^{-1}\right)$ expressa a média dos dados encontrados no campo. 


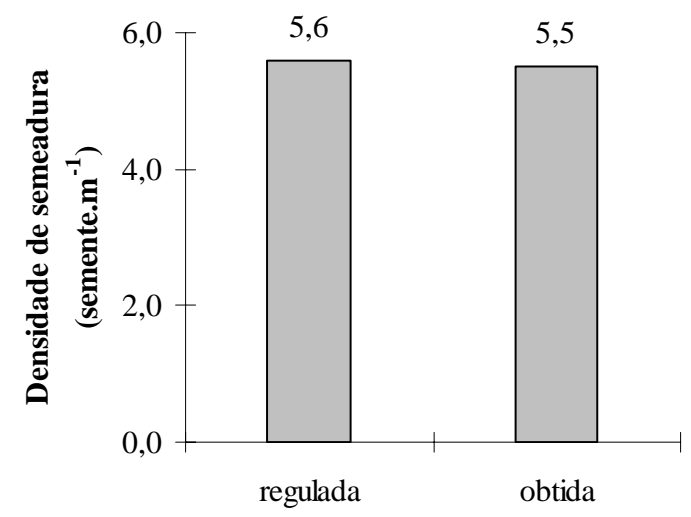

Figura 10 - Densidade de semeadura para a cultura do milho na propriedade

Outra informação demonstrada pelo indicador foi que o valor obtido ficou muito próximo ao regulado (Figura 10), mostrando que as semeadoras obedeceram à regulagem. Porém houve uma redução no estande final de plantas de 1,78\%, sendo possível dizer que o valor de densidade de semeadura encontrado é suficiente para atender as necessidades agronômicas das plantas. Contudo, o Iind calculado $(0,77)$ demonstra que o indicador pode ser melhorado no campo, principalmente, para o número de sementes abaixo do LIE.

\subsubsection{Distância entre a semente e o fertilizante}

Pode-se observar nos resultados apresentados na Tabela 6, que o indicador de distância entre a semente e o fertilizante não está regular para a operação, embora a média, mediana e moda tenham se apresentado com os valores muito próximos, indicando uma tendência dos dados estarem em torno da média.

O alto valor do coeficiente de variação, que pode ser explicado pelo valor da amplitude ser igual ao máximo, evidencia uma grande diferença entre os extremos. Isto demonstra que em alguns pontos da área as semeadoras colocaram as sementes junto ao fertilizante, enquanto que em outros, a distância foi elevada. A irregularidade na distância de distribuição não é desejada na operação de semeadura, pois quando se coloca o fertilizante junto à semente, podem-se causar danos e queda no índice de germinação. Em contrapartida, quando à distância entre o fertilizante e a semente é 
grande, pode ocorrer deficiência nutricional durante as primeiras etapas de desenvolvimento da plântula.

Tabela 6. Resultado da análise da estatística descritiva do indicador de distância entre a semente e o fertilizante

\begin{tabular}{cc}
\hline Descrição & Valor $(\mathbf{c m})$ \\
\hline Média & 2,68 \\
Mediana & 2,00 \\
Moda & 2,00 \\
Desvio padrão & 1,77 \\
CV \% & 66,04 \\
Curtose & 3,75 \\
Assimetria & 1,85 \\
Amplitude & 10,00 \\
Mínimo & 0,00 \\
Máximo & 10,00 \\
Número de Amostras & 807 \\
\hline
\end{tabular}

A distribuição dos dados apresentados na Figura 11 não demonstrou uma tendência à normalidade. Apesar dos dados se encontrarem ao redor da média $(2,68)$, demonstrando uma curva do tipo leptocúrtica, indicando a curva de frequências mais fechada que a normal (ou mais aguda em sua parte superior), e uma assimetria positiva.

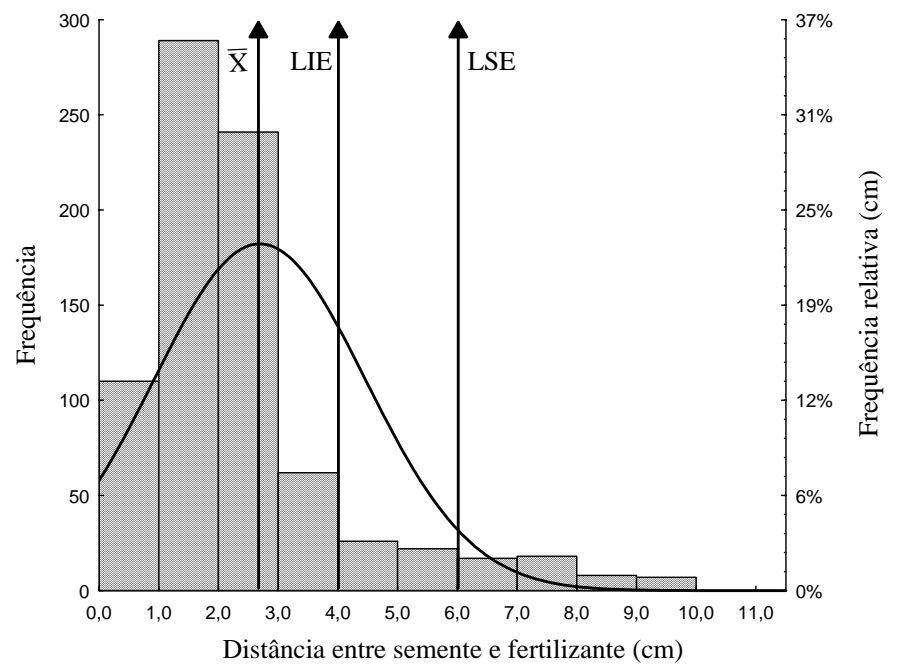

Figura 11 - Histograma de distribuição e curva normal dos dados do indicador da distância entre a semente e o fertilizante no solo 
Segundo recomendações agronômicas para a cultura do milho não existe um número ideal para a distância entre a semente e o fertilizante, recomendando-se entre 4,0 e 6,0 cm, mas esses valores podem mudar devido ao tipo de solo (textura), época de semeadura, região, cultivar adotado entre outros.

A Figura 11 demonstra que apenas 10\% dos dados do indicador distância entre semente e fertilizante ficaram dentro do intervalo recomendado, e que 84\% estão abaixo do LIE e 6\% acima do LSE. O Iind $(0,10)$ demonstra a necessidade de correções na execução do processo, atentando nos valores abaixo do LIE.

Para o estudo foi considerada a distância de 4,0 cm como aceitável para o processo, em função da região e do tipo de solo. Apresenta-se na Figura 12 a comparação entre o valor regulado e o valor médio obtido neste estudo, para a distância entre a semente e o fertilizante na linha de semeadura do milho.

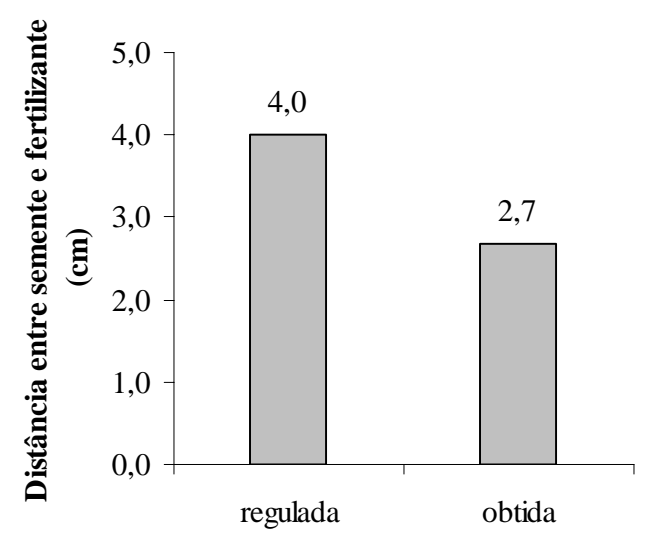

Figura 12 - Comparação entre o valor regulado e o obtido pelas semeadoras para o indicador de distância entre semente e o fertilizante

Na Figura 12 é possível observar que o valor do indicador de distância entre a semente e o fertilizante ficou abaixo do valor ideal regulado para as máquinas, demonstrando a necessidade de melhora no processo. É necessário um aumento da distância entre os insumos (semente e fertilizantes) dentro do solo na ordem de 67\%, para poder alcançar o valor agronômico para qual a semeadora foi regulada, evitando assim possíveis prejuízos para a germinação das sementes. 


\subsubsection{Distância entre sementes no sulco}

A Tabela 7 mostra que o indicador da distância entre as sementes no sulco da semeadura não apresenta uma distribuição regular, com grande variabilidade confirmada pelos valores do desvio padrão e coeficiente de variação do conjunto de dados, ainda que os valores da média, mediana e moda tenham apontado uma tendência de concentração em torno da média.

O alto coeficiente de variação é devido ao fato de que o valor de máximo está muito perto da amplitude, indicando que as semeadoras em alguns pontos depositaram as sementes muito próximas uma das outras, caracterizando um espaçamento duplo, e em outros pontos colocaram a uma distância excessiva o que indica uma classificação de falha na linha de semeadura. Essa irregularidade da distância entre as sementes no sulco da semeadura prejudica a formação de um estande adequado de plantas, influenciando diretamente, de forma negativa, na produtividade da cultura.

Tabela 7. Resultado da análise da estatística descritiva do indicador distância entre sementes no sulco

\begin{tabular}{cc}
\hline Descrição & Valor $(\mathbf{c m})$ \\
\hline Média & 18,15 \\
Mediana & 18,00 \\
Moda & 18,00 \\
Desvio padrão & 4,44 \\
CV\% & 24,45 \\
Curtose & 2,21 \\
Assimetria & 0,53 \\
Amplitude & 40,00 \\
Mínimo & 1,00 \\
Máximo & 41,00 \\
Número de amostras & 4837 \\
\hline
\end{tabular}

O coeficiente de curtose positivo aponta uma tendência dos dados concentraremse em torno da média, apresentando uma curva leptocúrtica, como é possível observar na Figura 13. O valor positivo da assimetria indica que as semeadoras apresentaram uma tendência de colocar as sementes mais separadas dentro do sulco, o que não é interessante para a operação, por ocasionar falhas nos espaçamentos, e conseqüentes 
perdas na produtividade.

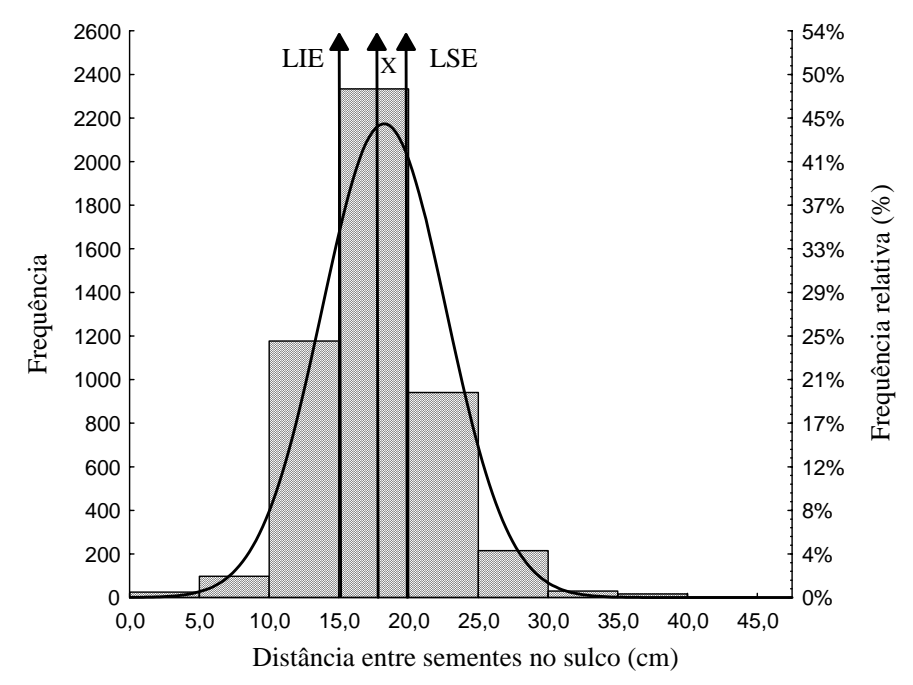

Figura 13 - Histograma de distribuição e curva normal dos dados do indicador distância entre as sementes no sulco da semeadura

Para a determinação da distância entre as sementes no sulco foram observados o estande final e a densidade de semeadura, tendo como valor ideal à distância de 17,9 cm para o processo.

Na Figura 14 é apresentada a classificação dos espaçamentos, adaptada de Vieira Junior et al. (2004) que determinaram por meio do coeficiente de variação (CV,\%) das distâncias entre plantas na linha de semeadura o indicativo da homogeneidade da distribuição espacial das sementes. De acordo com a classificação adaptada, variação superior a 30\% do valor ideal $(23,3 \mathrm{~cm})$ é denominada de espaçamento inaceitável falho, entre 15 e 30\% superior ao valor ideal (20,7 a 23,2 cm) de espaçamento falho, na faixa de $15 \%$ a mais ou a menos do valor ideal $(15,2$ a $20,6 \mathrm{~cm})$ é considerado espaçamento aceitável, entre 15 e 30\% inferior (15,1 a 12,6 cm) é classificado como espaçamento duplo, e variações 30\% inferiores $(12,5 \mathrm{~cm})$ de inaceitável duplo. 


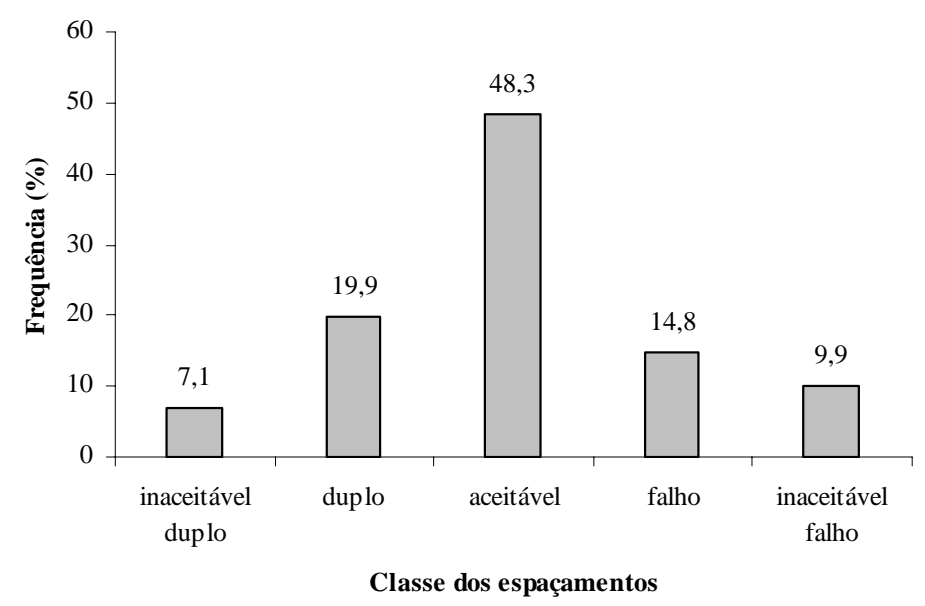

Figura 14 - Classificação dos espaçamentos encontrados para o indicador distância entre as sementes no sulco da semeadura

Dos valores obtidos mais de $50 \%$ dos espaçamentos estão fora do intervalo considerado como aceitável para a distribuição de sementes na operação, e uma necessidade de melhora de $27 \%$ nos espaçamentos duplos e 24,7\% para falhos. Esses espaçamentos que ficaram fora do limite aceitável (52\%) irão comprometer a produção de grãos na lavoura, reforçando a necessidade de melhorias no processo de semeadura para a distribuição espacial das sementes.

São apresentados na Figura 15 os valores obtidos na bibliografia e no estudo para o indicador de distância entre sementes no sulco de semeadura, considerando os espaçamentos aceitáveis, duplos e falhos conforme norma ABNT (1989). 


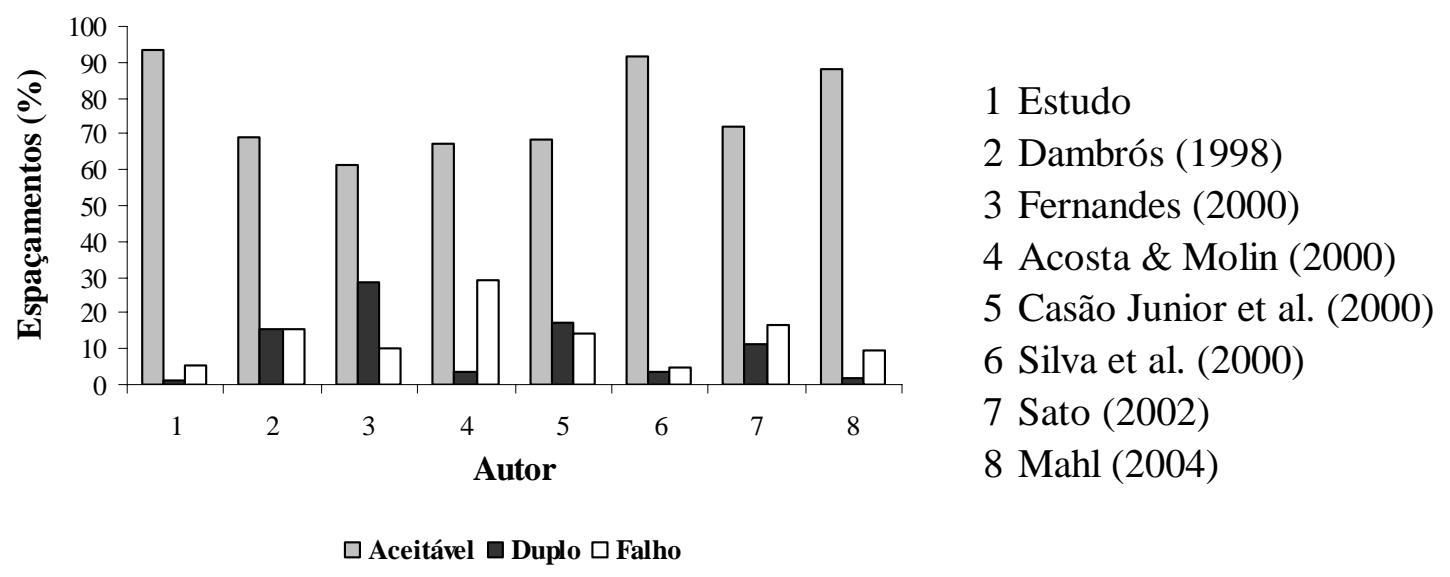

Figura 15 - Comparação entre os valores obtidos na bibliografia e no estudo para o indicador de distancia entre sementes no sulco

É possível observar na Figura 15 que a porcentagem do valor de espaçamento aceitável no estudo aumentou para 93\%, ao se utilizar à norma da ABNT (1989). Esse valor quando comparado com os valores encontrados na bibliografia demonstra que o processo apresenta o melhor resultado de todos. Entretanto, vale destacar que a norma para classificação dos espaçamentos omite as variações dentro do processo, por apresentar um intervalo de espaçamentos aceitáveis amplo, 50\% acima e abaixo da distância ideal entre sementes, não podendo ser utilizada como único parâmetro de avaliação.

\subsubsection{Emergência de plantas}

A análise da Tabela 8 demonstra uma regularidade para o indicador de emergência de plantas por metro. As pequenas diferenças entre os valores da média, mediana e moda indicam que os dados apresentaram uma tendência de estarem abaixo da média, não existindo variações significativas entre os resultados (baixo desvio padrão e coeficiente de variação).

A alta amplitude expressa pela diferença entre os valores extremos, pode ser explicada pela não germinação de algumas sementes, o que ocasionou falhas na linha de semeadura. Contudo pode-se dizer que as sementes apresentaram uniformidade quanto à germinação. 
Tabela 8. Resultado da análise da estatística descritiva do indicador de emergência de plantas

\begin{tabular}{cc}
\hline Descrição & Valor $\left(\right.$ plantas. $\left.\mathbf{m}^{\mathbf{- 1}}\right)$ \\
\hline Média & 5,50 \\
Mediana & 5,40 \\
Moda & 5,40 \\
Desvio padrão & 0,62 \\
CV\% & 2,24 \\
Curtose & 0,90 \\
Assimetria & 0,81 \\
Amplitude & 3,60 \\
Mínimo & 4,20 \\
Máximo & 7,80 \\
Número de amostras & 164 \\
\hline
\end{tabular}

Na Figura 16 o histograma apresenta uma assimetria levemente positiva e curva do tipo leptocúrtica, com tendência dos dados estarem em torno da média. Por meio desses dois parâmetros avaliados (coeficiente de assimetria e curtose) é possível dizer que este indicador apresentou baixa variabilidade no processo da semeadura, indicando uma tendência à normalidade de distribuição dos dados, 96\% das sementes que foram depositadas no sulco de semeadura germinaram, por meio dos valores obtidos na semeadura e na emergência das plantas, não tendo Iind igual a 1,0 devido às sementes que ficaram expostas, fora do sulco de semeadura. Por meio do indicador, observa-se que a germinação atingiu o critério estabelecido na semeadura, não sendo necessárias alterações ou revisões no processo. 


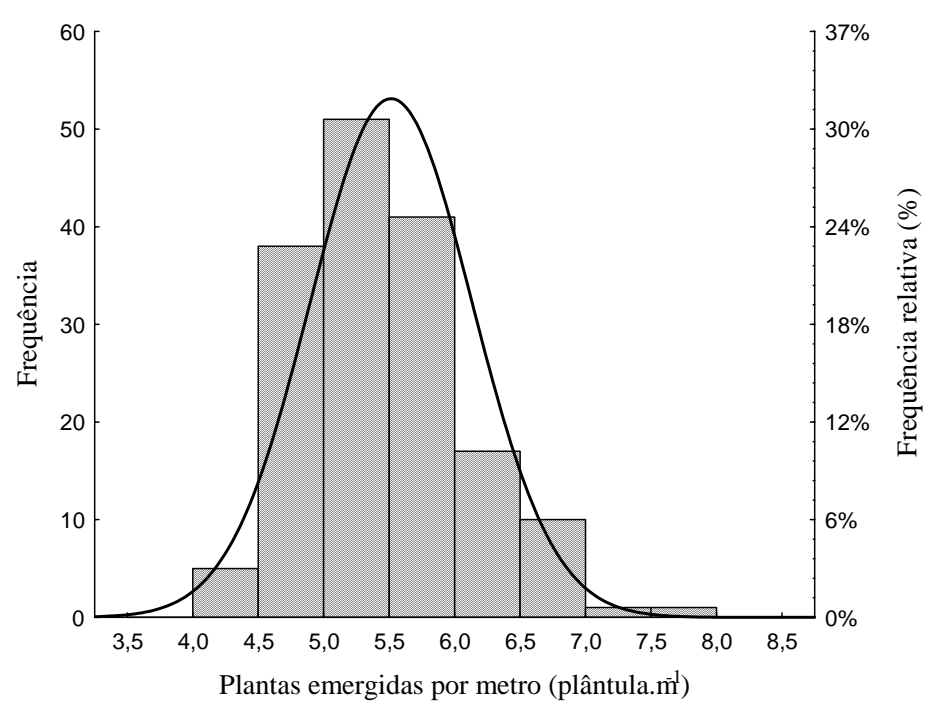

Figura 16 - Histograma de distribuição e curva normal dos dados do indicador emergência de plantas

\subsubsection{Profundidade da semente}

Conforme a Tabela 9 o indicador de profundidade da semente apresentou-se irregular durante o processo de semeadura, com as semeadoras não conseguindo manter uma profundidade constante para as sementes.

A pequena diferença apresentada entre a média, mediana e moda e o alto valor do coeficiente de curtose caracterizou uma tendência dos dados se apresentarem em torno da média. Apesar dessa tendência de concentração, a irregularidade das profundidades das sementes foi notada e confirmada pelos elevados valores obtidos no coeficiente de variação e amplitude. A existência de variações significativas demonstra que as semeadoras depositavam as sementes muito próximas à superfície do solo $(1,50 \mathrm{~cm})$ ou em profundidades altas $(8,00 \mathrm{~cm})$. Este fato provoca uma germinação irregular das sementes do milho prejudicando o estande final de plantas, além de que, as sementes que germinarem primeiro as plantas são mais sensíveis à falta de água podendo morrer e ocasionar falhas na linha de semeadura. As sementes que apresentarem germinações tardias, ocasionadas pela profundidade elevada, após a emergência podem apresentar desenvolvimento aquém das plantas vizinhas e com prejuízos a formação de espigas (plantas dominadas), o que influi na produtividade da cultura. 
Tabela 9. Resultado da análise da estatística descritiva do indicador profundidade da semente

\begin{tabular}{cc}
\hline Descrição & Valor $(\mathbf{c m})$ \\
\hline Média & 3,88 \\
Mediana & 4,00 \\
Moda & 4,00 \\
Desvio padrão & 0,88 \\
CV\% & 22,68 \\
Curtose & 1,47 \\
Assimetria & 0,84 \\
Amplitude & 6,50 \\
Mínimo & 1,50 \\
Máximo & 8,00 \\
Número de amostras & 807 \\
\hline
\end{tabular}

Segundo consta na Figura 17, a curva normal apresentada é do tipo leptocúrtica com os dados concentrados em torno da média, tendo uma assimetria positiva indicando que as semeadoras apresentaram uma tendência de depositar as sementes em profundidades maiores. Essa tendência não é desejada para a operação, pois ocasiona a desuniformidade na germinação e o estande desigual. Ocasiona perdas em produtividade, devido às diferenças no consumo de energia que as plântulas terão para conseguir a emergência, bem como as diferentes quantidades de água disponíveis no perfil do sulco de semeadura. Além disso, a irregularidade na germinação das sementes ocasiona maior dificuldade no controle de doenças, uma vez que plantas em diferentes estádios possuem disparidade na suscetibilidade às doenças. 


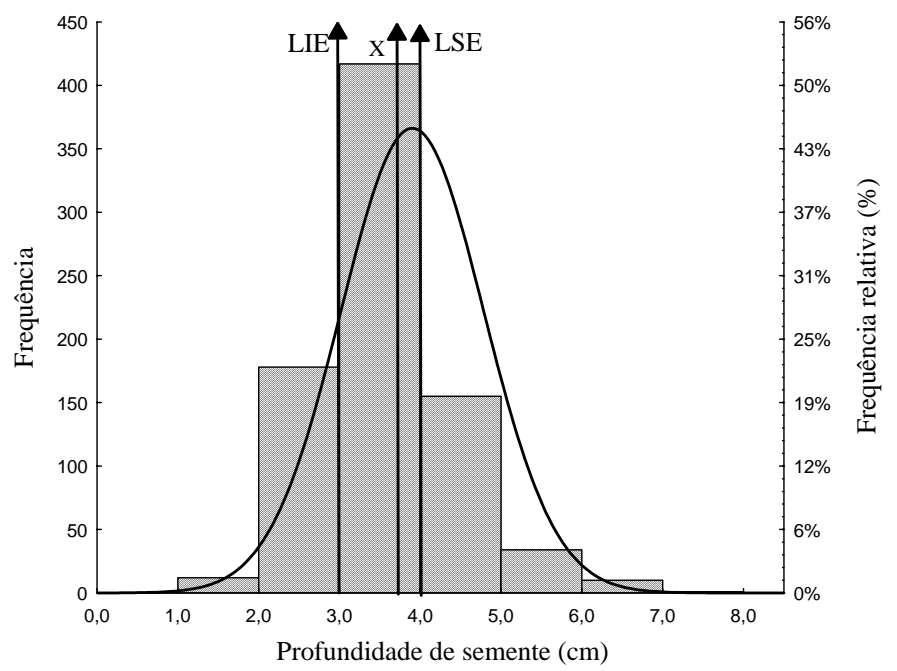

Figura 17 - Histograma de distribuição e curva normal dos dados do indicador de profundidade de semente

Na Figura 17 observa-se que 52\% dos valores ficaram dentro do intervalo desejado para o processo (3,0 a 4,0 cm) e que 23\% estão abaixo do LIE e 25\% acima do LSE, tendo Iind igual a 0,52. O indicador mostra que $48 \%$ das sementes encontram-se em profundidades inadequadas para a germinação.

Para o processo de semeadura as máquinas foram reguladas para depositar a semente a 4,0 cm no solo, profundidade considerada como ideal para o milho. É apresentado na Figura 18 o valor regulado e o obtido no campo para a profundidade de semeadura do milho. 


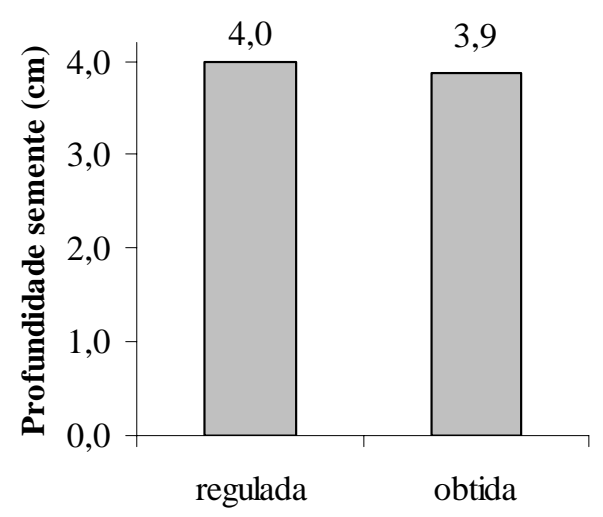

Figura 18 - Comparação entre o valor regulado para a máquina e o obtido pelo indicador de profundidade da semente

Pela análise da Figura 18 pode-se dizer que os valores apresentaram-se muito próximos não necessitando de melhorias para o indicador, mas essa informação por si só é incompleta. Existem variações no processo, demonstradas pelas sementes que ficaram em profundidades irregulares, fora dos limites (Figura 17) e um alto valor do CV $(22,68 \%)$.

\subsubsection{Profundidade do fertilizante}

Na análise da Tabela 10 permite-se observar que o indicador de profundidade do fertilizante apresentou irregularidade, com um coeficiente de variação elevado, mesmo quando a média, mediana e moda apresentaram valores próximos indicando uma tendência dos dados encontrarem-se em torno da média. Essa irregularidade também é comprovada pelo valor da amplitude, uma vez que a mesma está muito próxima do valor máximo, indicando que, em alguns momentos as semeadoras depositaram o fertilizante em profundidades elevadas $(14,0 \mathrm{~cm})$. Essa forma de operar das semeadoras não é almejada, tendo em vista que o insumo não será utilizado pela semente e poderá ocasionar decréscimos na produção, além de aumentar os custos da cultura. 
Tabela 10. Resultado da análise da estatística descritiva do indicador de profundidade do fertilizante

\begin{tabular}{cc}
\hline Descrição & Valor $(\mathbf{c m})$ \\
\hline Média & 6,56 \\
Mediana & 6,00 \\
Moda & 6,00 \\
Desvio padrão & 2,11 \\
CV\% & 32,16 \\
Curtose & 1,52 \\
Assimetria & 1,44 \\
Amplitude & 11,00 \\
Mínimo & 3,00 \\
Máximo & 14,00 \\
Número de amostras & 807 \\
\hline
\end{tabular}

Como é possível observar na Figura 19 a curva possui uma assimetria positiva, o que indica uma tendência das semeadoras depositarem o adubo em profundidades maiores, e é levemente leptocúrtica com os dados concentrados em torno da média. Pode-se notar a elevada dispersão dos dados com uma concentração dos valores de profundidade do fertilizante entre 5,0 e 6,0 cm (31\%) e, também, que menos de 2\% dos dados ficaram dentro dos limites estabelecidos para o processo, tendo Iind muito baixo $(0,018)$ quando comparado com o valor ideal $(1,0)$. Houve uma alta concentração dos dados (85\%) abaixo do LIE, o que implica em uma deposição de fertilizante junto à semente no sulco de semeadura. 


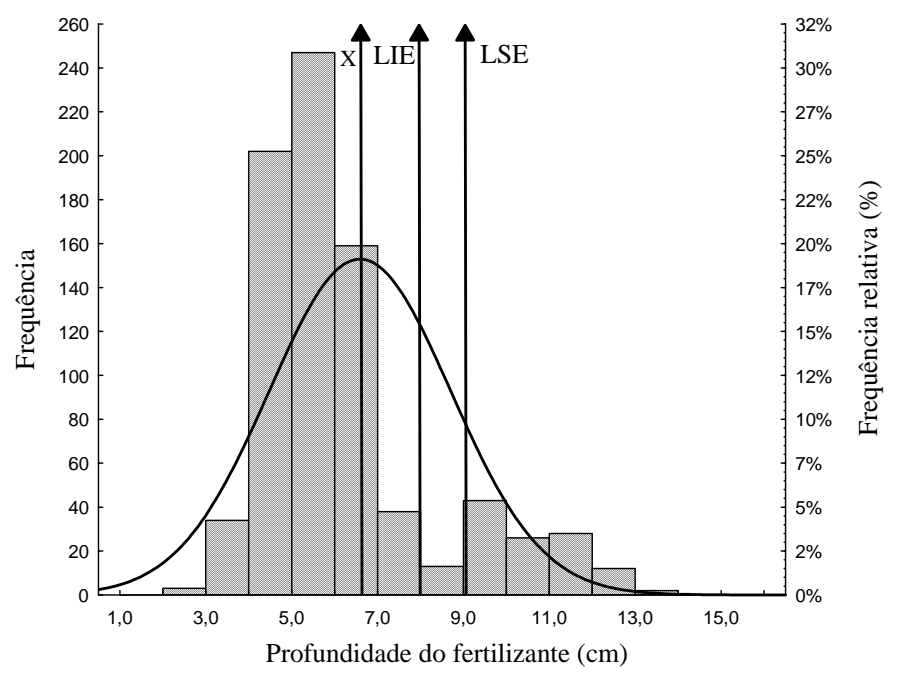

Figura 19 - Histograma de distribuição e curva normal dos dados do indicador de profundidade do fertilizante

Para o processo, o valor da profundidade do fertilizante foi regulado nas semeadoras para 8,0 cm, respeitando-se à distância de 4,0 $\mathrm{cm}$ abaixo da semente e mantendo-se dentro do intervalo citado na bibliografia. Na Figura 20 são encontrados os valores para a regulagem feita nas semeadoras e o valor médio encontrado no campo para o indicador profundidade do fertilizante.

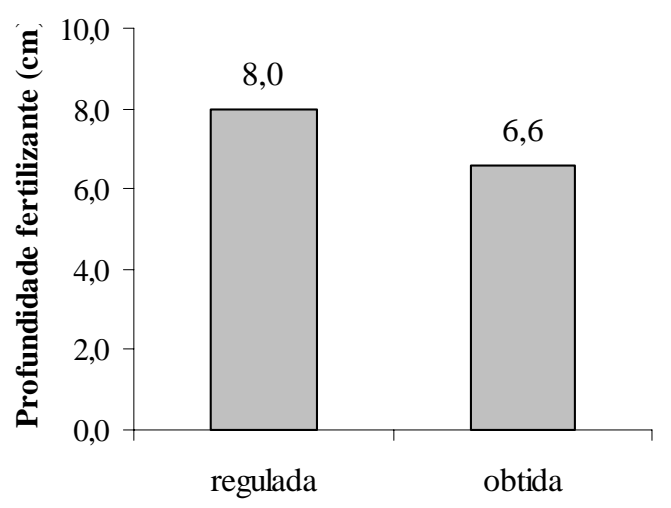

Figura 20 - Comparação entre o valor regulado e o obtido para o indicador de profundidade do fertilizante

Os valores obtidos foram menores do que o previsto (regulado), Figura 20, deixando o fertilizante mais próximo da semente no solo, o que mostra uma necessidade 
de melhora, para evitar o efeito da salinização e provável redução do poder germinativo das sementes. A comparação dos valores mostra que se deve aumentar está profundidade em 18\% para atingir o valor desejado na operação.

\subsubsection{Sementes entre palha}

Por meio da análise da Tabela 11 é possível constatar que o indicador de sementes entre palha apresentou-se regular para a operação, com um baixo desvio padrão e uma pequena diferença entre as medidas de tendência central (média, mediana e moda). O alto valor do coeficiente de variação (855,55\%) se deve ao fato da amplitude apresentar valor igual ao do máximo. Está análise demonstra que as semeadoras deixaram poucas sementes entre a palha sem contato com o solo, o que contribuiu para a germinação uniforme.

Tabela 11. Resultado da análise da estatística descritiva do indicador do número de sementes entre a palha na operação de semeadura

\begin{tabular}{cc}
\hline Descrição & Valor (sementes) \\
\hline Média & 0,02 \\
Mediana & 0,00 \\
Moda & 0,00 \\
Desvio padrão & 0,16 \\
CV \% & 855,55 \\
Curtose & 99,56 \\
Assimetria & 9,55 \\
Amplitude & 2,00 \\
Mínimo & 0,00 \\
Máximo & 2,00 \\
Número de Amostras & 264 \\
\hline
\end{tabular}

Observa-se na Figura 21 uma simetria na distribuição dos dados para este indicador e uma curva do tipo leptocúrtica que mostra uma tendência dos dados estarem em torno da média, tendência essa reforçada pelo coeficiente de curtose altamente positivo. 


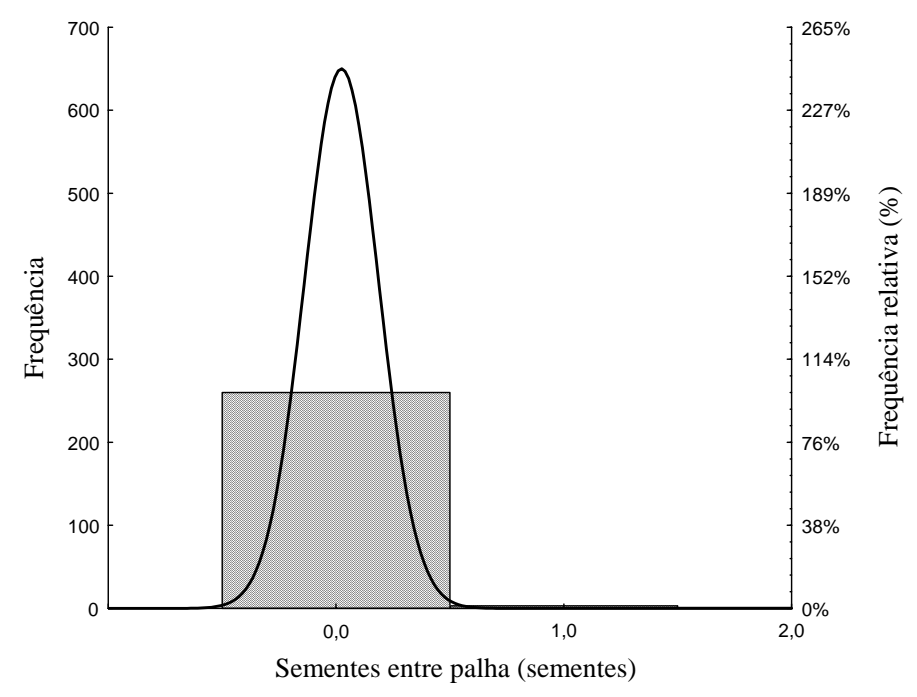

Figura 21 - Histograma de distribuição e curva normal dos dados do indicador de sementes entre palha

A Figura 22 mostra o valor para o indicador de sementes entre palha encontrado no campo e o desejado na regulagem. As máquinas foram reguladas para não deixarem nenhuma semente fora do sulco em contato com a palha, visando o maior número de sementes possível dentro do solo aptas à germinação. A Figura 23 mostra a comparação do valor do estudo com a bibliografia.

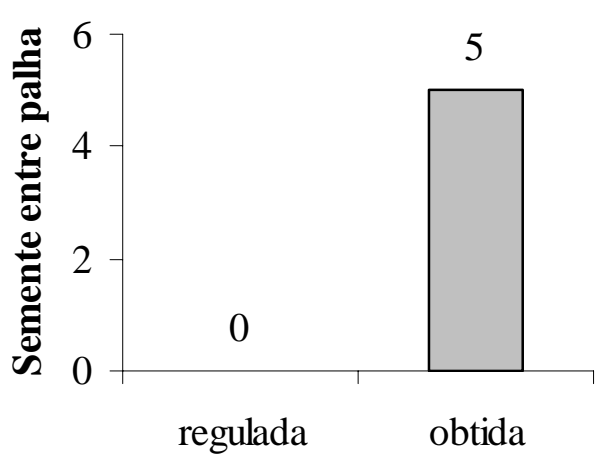

Figura 22 - Valor regulado na semeadora e obtido na operação para 0 indicador de sementes entre palha

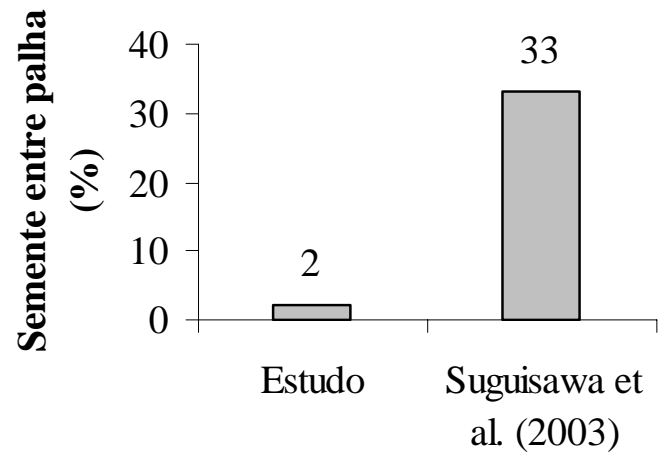

Figura 23 - Valor encontrado no estudo e na bibliografia para sementes entre palha na operação de semeadura direta do milho 
Na análise da Figura 22 é possível observar que apenas cinco sementes ficaram sobre a palha (2\%) resultando no Iind igual a 0,98. O indicador encontra-se satisfatório para a operação, não tendo necessidade de interferência no processo. Quando comparado com outro trabalho (Figura 23) apresenta valor menor para o mesmo indicador avaliado no processo.

\subsubsection{Sementes expostas}

Na Tabela 12 observa-se que o indicador de sementes expostas encontra-se regular para a operação de semeadura da cultura do milho, demonstrado por meio dos valores obtidos da média, mediana e moda, e desvio padrão baixo.

O elevado coeficiente de variação (600,81\%) se deve ao fato da amplitude ter valor igual ao valor máximo, ou seja, ocorreram pontos isolados dentro do talhão em que as sementes estavam expostas.

Com este indicador, é possível afirmar que as semeadoras apresentaram um desempenho satisfatório na operação, porque deixaram poucas sementes sobre o solo fora do sulco de semeadura, o que resulta em menores desperdícios desse insumo no campo e contribui para a formação de uma população de plantas adequada no estande.

Tabela 11. Resultado da análise da estatística descritiva do indicador de sementes expostas

\begin{tabular}{cc}
\hline Descrição & Valor (sementes) \\
\hline Média & 0,04 \\
Mediana & 0,00 \\
Moda & 0,00 \\
Desvio padrão & 0,23 \\
CV \% & 600,81 \\
Curtose & 47,41 \\
Assimetria & 6,64 \\
Amplitude & 2,00 \\
Mínimo & 0,00 \\
Máximo & 2,00 \\
Número de Amostras & 264 \\
\hline
\end{tabular}


A curva apresentada na Figura 24 é do tipo leptocúrtica e indica uma simetria na distribuição dos dados, confirmada pelos valores das medidas de tendência central (média, mediana e moda). O indicador apresentou uma distribuição caracterizada por uma curtose altamente positiva, tendendo os dados estarem em torno da média.

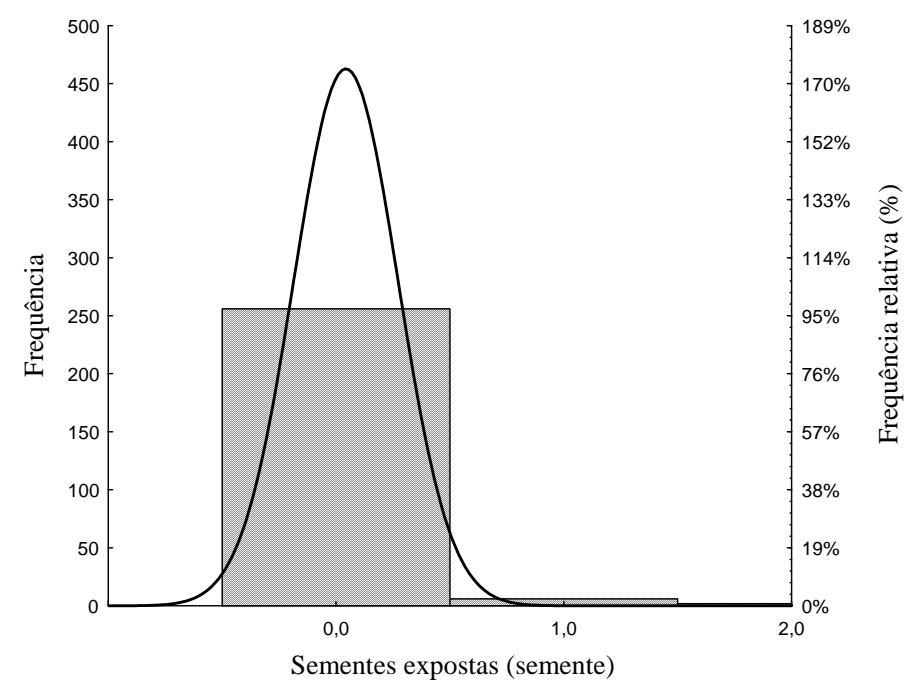

Figura 24 - Histograma de distribuição e curva normal dos dados do indicador de sementes expostas

A Figura 25 traz o valor regulado e o obtido no trabalho para o indicador de sementes expostas. As máquinas foram reguladas para colocarem todas as sementes dentro do sulco de semeadura, conseqüentemente nenhuma semente deveria ficar exposta.

Deve-se destacar que os valores para o indicador de semente entre palha e exposta são iguais (zero), porque todas as sementes que ficarem fora do sulco de semeadura vão influenciar diretamente as porcentagens de plantas, causando as seguintes falhas: espaçamentos; número de plantas por metro linear; heterogeneidade entre as fileiras; estande final; fatal redução na produtividade. 


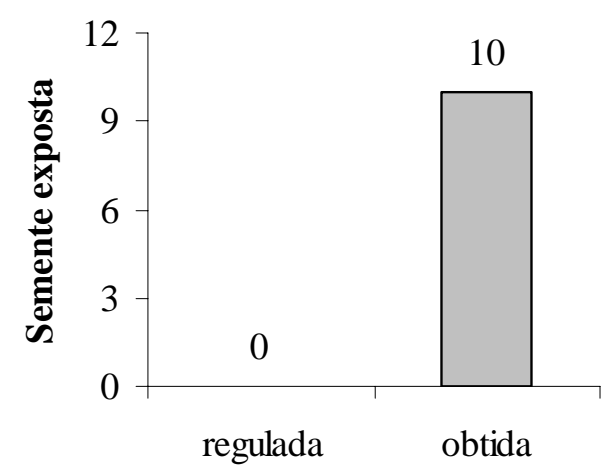

Figura 25 - Valor regulado na semeadora e obtido na operação para o indicador de sementes expostas

Como mostra na Figura 25, pela comparação dos valores, é necessário uma redução no número de sementes expostas no processo de semeadura para se atingir o valor regulado para a operação, apesar de que em toda a área apenas dez sementes (3,79\%) ficaram expostas. O Iind apresentou valor igual a 0,96.

A Figura 26 traz os valores para comparação encontrados na bibliografia e no estudo para o indicador de sementes expostas.

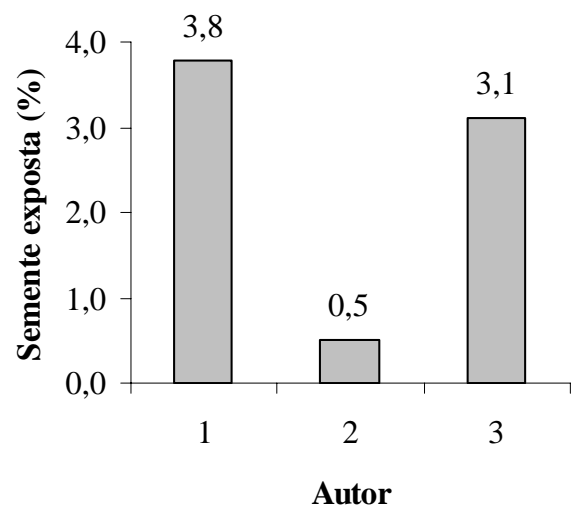

1 Estudo

2 Casão Junior et al. (2000)

3 Suguisawa (2003)

Figura 26 - Comparação entre o estudo e os valores obtidos na bibliografia para o indicador de sementes expostas

Mesmo com Iind igual a 0,96 estando próximo ao ideal teórico $(1,0)$, quando se compara o valor do indicador com valores de bibliografia (Figura 26) nota-se que ele apresentou a maior porcentagem, o que indica que é possível reduzir o valor dentro do 
processo.

\subsubsection{Solo mobilizado}

É possível observar que na Tabela 13 existiu uma grande variabilidade para o indicador de solo mobilizado, comprovados pelos valores do coeficiente de variação e desvio padrão que foram encontrados. O valor da média é inferior à mediana e moda, demonstrando que os valores se encontraram na maioria das vezes acima da média retratando um maior revolvimento do solo.

A amplitude apresentou valor próximo ao máximo, demonstrando que as semeadoras em alguns pontos mobilizaram quantidades maiores de solo, fato não desejado durante a operação.

Tabela 12. Resultado da análise da estatística descritiva do indicador de solo mobilizado

\begin{tabular}{cc}
\hline Descrição & Valor $\mathbf{( c m})$ \\
\hline Média & 18,92 \\
Mediana & 19,00 \\
Moda & 20,00 \\
Desvio padrão & 3,70 \\
CV\% & 19,53 \\
Curtose & 0,94 \\
Assimetria & 0,24 \\
Amplitude & 24,00 \\
Mínimo & 9,00 \\
Máximo & 33,00 \\
Número de amostras & 269 \\
\hline
\end{tabular}

Observa-se na Figura 27 que a curva é do tipo leptocúrtica tendo valores concentrados em torno da média, e uma assimetria levemente positiva com as semeadoras tendendo a revolver mais o solo durante a operação. Contudo nota-se uma alta dispersão dos dados para este indicador, o que indicou uma irregularidade no revolvimento do solo não desejado para a operação, pois as semeadoras em alguns pontos causaram uma abertura na palha, e em outros não. Esse comportamento expõe o solo a fatores ambientais como: gotas de chuva, causando a desagregação de partículas e compactação; raios solares, aumentando a evaporação e, conseqüentemente, diminuindo 
a quantidade de água disponível; escorrimento superficial; e plantas daninhas.

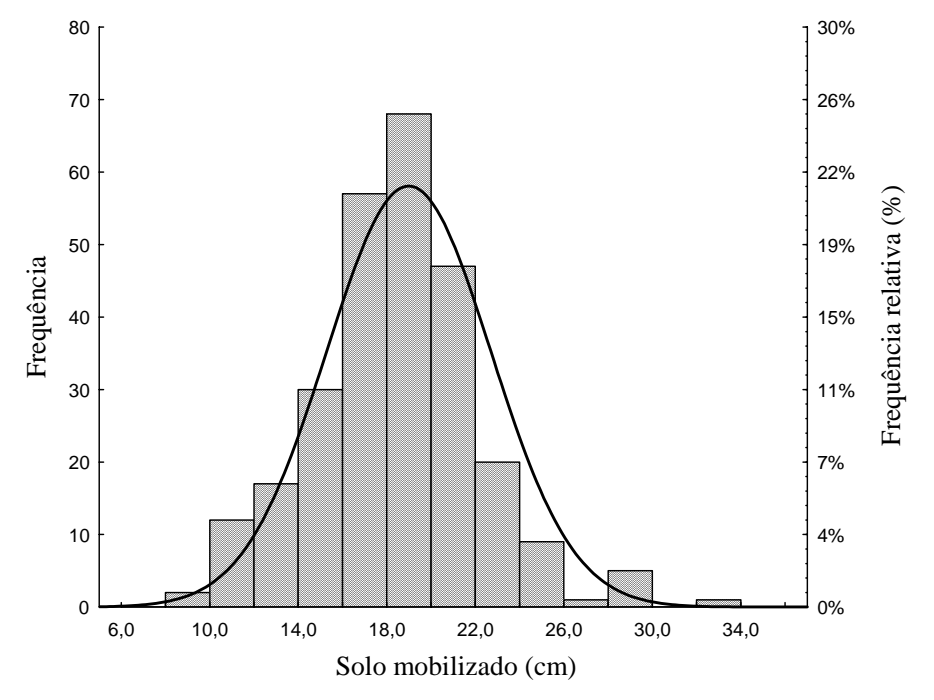

Figura 27 - Histograma de distribuição e curva normal dos dados do indicador de solo mobilizado

Não foram encontrados valores agronômicos na bibliografia consultada para a comparação com o indicador. Portanto, foi considerado o valor do coeficiente de variação (19,53\%), que mede a dispersão dos dados em relação à média. O indicador demonstrou, segundo classificação apresentada por Pimentel-Gomes \& Garcia (2002), um valor médio para o processo.

\section{6 Índice de Qualidade do Processo (IQP)}

Na Tabela 13 é apresentada a porcentagem de cada indicador que ficou abaixo do LIE e acima do LSE, e os índices dos indicadores (Iind) calculados pela equação 01.

Nota-se que os indicadores distância entre semente e fertilizante e profundidade do fertilizante foram os que apresentaram as maiores porcentagens de valores fora dos limites especificados para o processo, 90\% e 98\% respectivamente. Os indicadores emergência de plantas, sementes entre palha e exposta tiveram valores acima de 95\% dentro dos limites. O indicador de emergência de plantas obteve 100\% dos valores na faixa especificada pelo corpo técnico. 
Tabela 13. Porcentagens abaixo e acima dos limites especificados e índice dos indicadores

\begin{tabular}{lccc}
\hline INDICADOR & Abaixo LIE (\%) & Acima LSE (\%) & Iind. \\
\hline Densidade de semeadura & 21 & 2 & 0,77 \\
Distância entre semente e fertilizante & 84 & 6 & 0,10 \\
Distância entre sementes no sulco & 27 & 25 & 0,48 \\
Emergência de plantas & 0 & 0 & 0,96 \\
Profundidade da semente & 23 & 25 & 0,52 \\
Profundidade do fertilizante & 85 & 13 & 0,02 \\
Semente entre palha & 0 & 2 & 0,98 \\
Semente exposta & 0 & 4 & 0,96 \\
\hline
\end{tabular}

Apresenta-se na Figura 28 um quadro geral dos indicadores de desempenho do processo de semeadura, sendo que os valores que mais se aproximam de 1,0 melhor contribuem para a qualidade do processo no campo.

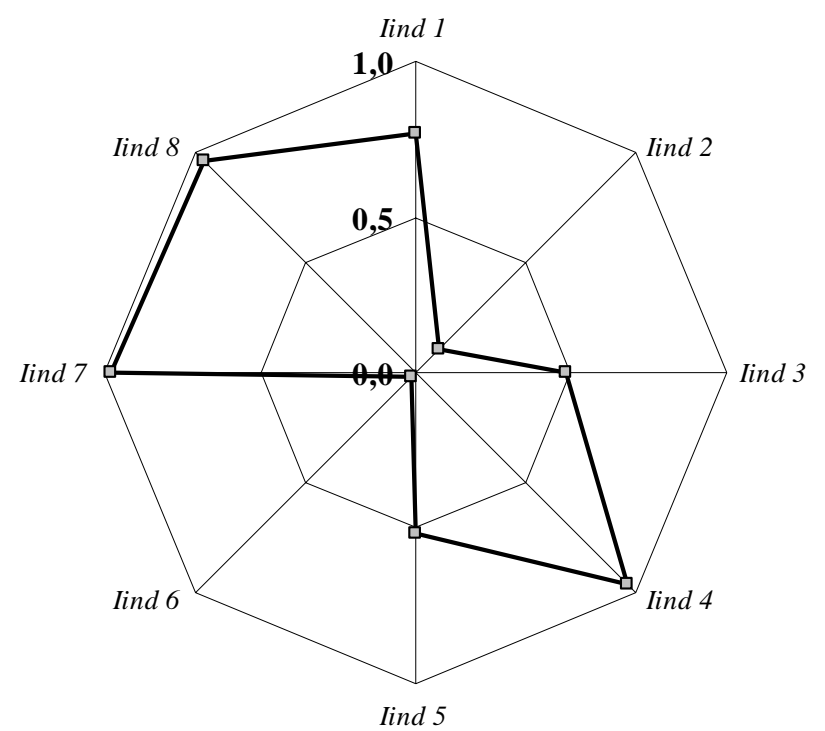

Figura 28 - Gráfico dos Iind do processo de semeadura
Iind 1 = índice do indicador densidade de semeadura

Iind 2 = índice do indicador distância entre semente e fertilizante

Iind 3 = índice do indicador distância entre sementes no sulco

Iind 4 = índice do indicador emergência de plantas

Iind 5 = índice do indicador profundidade de semente

Iind 6 = índice do indicador profundidade de fertilizante

Iind 7 = índice do indicador semente entre palha

Iind 8 = índice do indicador semente exposta 
Verifica-se na Figura 28 que os Iind 2 e 6 foram os que mais se aproximaram do centro do gráfico diminuindo a qualidade do processo e os Iind 4, 7 e 8 ficaram próximos do valor ideal.

Utilizando-se os valores apresentados na Tabela 13 foi calculado o IQP para a semeadura, equação 03. Os indicadores utilizados foram: densidade de semeadura, distância entre semente e fertilizante, distância entre sementes no sulco, profundidade de semente e do fertilizante, semente entre palha e exposta. $\mathrm{O}$ indicador de solo mobilizado não foi considerado por não apresentar valores de referência na bibliografia.

$$
\begin{aligned}
& I Q P=\frac{1}{n} *(\operatorname{Iind} 1+\operatorname{Iind} 2+\operatorname{Iind} 3+\operatorname{Iind} 4+\operatorname{Iind} 5+\operatorname{Iind} 6+\operatorname{Iind} 7+\operatorname{Iind} 8) \\
& I Q P=0,60
\end{aligned}
$$

onde,

$I Q P=$ Índice de Qualidade do Processo

$n$ = número de indicadores utilizados no processo

O IQP demonstra que na operação de semeadura $60 \%$ dos valores dos indicadores estão dentro dos limites especificados pelo corpo técnico da empresa, considerados como ideais para a cultura do milho, e mostra que $40 \%$ ficaram fora desses limites, sendo está porcentagem dividida da seguinte maneira, 30\% dos valores abaixo do LIE e 10\% acima do LSE. O IQP é um índice geral, mas é possível analisar cada indicador individualmente por meio do Iind. Da análise individual detectou-se que os indicadores distância entre semente e fertilizante e profundidade do fertilizante foram os que mais influenciaram negativamente a qualidade do processo de semeadura no campo. 


\section{CONCLUSÕES}

A metodologia proposta permitiu obter um sistema de informações para o processo de semeadura direta do milho. Com o IQP foi possível identificar que o processo necessita de melhorias, e por meio do Iind realizou-se a análise individual de cada indicador detectando aqueles que influenciaram negativamente a qualidade da operação.

Para os indicadores coletados de profundidade da semente e fertilizante, distância entre semente e fertilizante, distância entre sementes no sulco e solo mobilizado estes apresentaram irregularidades durante o processo, que indicaram uma necessidade de mudança na operação para não prejudicar a produtividade da cultura de milho.

O indicador densidade de semeadura demonstrou que as semeadoras utilizadas para a operação possuem uma tendência em diminuir a quantidade de sementes depositadas no sulco. Os indicadores de sementes entre palha e exposta demonstraram uma baixa variabilidade para o processo de semeadura, contribuindo para uma melhor produtividade.

A regularidade do indicador de emergência de plantas demonstrou que as semeadoras utilizadas no processo apresentaram uma normalidade para a operação, o que veio a contribuir para a formação de um estande adequado de plantas. 
ANEXOS 


\section{Anexo A: Máquinas agrícolas e insumos utilizados no processo de semeadura *}

O processo de semeadura da cultura do milho teve inicio no dia 17 de setembro e término em 06 de outubro de 2003, nos talhões nomeados dentro da propriedade como 01, 02, 03, 07, 14, 15, 16 e 17, que somados totalizam uma área de 993 hectares. Os híbridos de milho utilizados na operação foram às variedades Tork, Penta e AG6018 $\left(\right.$ Syngenta $^{\circledR}$ ), DKB-215 e DKB-214 (Dekalb ${ }^{\circledR}$ ), P30F44 e P30F33 (Pioneer ${ }^{\circledR}$ ). Foram utilizados seis conjuntos mecanizados, compostos por uma semeadora-adubadora de fluxo contínuo da marca Semeato, modelo SSM27 (Figura 28A), e cinco semeadorasadubadoras da marca John Deere, modelo 913 Vacumeter (Figura 28B). Os tratores utilizados para arrastar as semeadoras foram da marca John Deere, modelos 7500 4X2 TDA com $103 \mathrm{~kW}(140 \mathrm{cv})$ de potência.
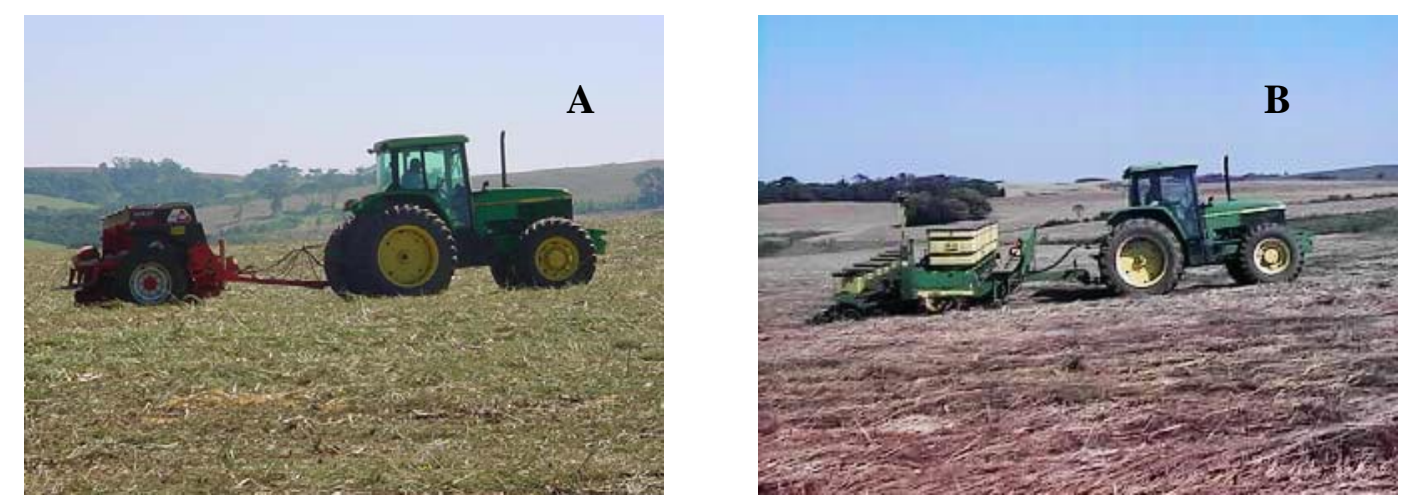

Figura 28 - Semeadora Semeato SSM27 (A) e semeadora 913 Vacumeter (B) acopladas ao trator durante a operação de semeadura

\footnotetext{
* As marcas e modelos citados neste trabalho não refletem a preferência do autor.
} 
Anexo B: Procedimento operacional para coleta dos indicadores no processo de semeadura - (PO)

\section{Tamanho e Número de Amostras}

A amostragem deve ser realizada no talhão quatro vezes ao dia, sendo uma pela manhã até às 9:30, uma das 10:00 até as 11 horas, uma das 13:00 até as 14:30; e a última ao entardecer das 17 horas até às 18:00. Deverá ser coletada uma linha de forma aleatória para cada amostra e semeadora utilizada durante a operação. As linhas e a máquina devem ser devidamente identificadas.

\section{Coleta dos Dados}

1. Após identificar o número da máquina e o número da linha, deve-se medir ao acaso 3,0 metros de comprimento na linha semeada com milho.

2. Medir o revolvimento do solo com uma trena, considerando apenas o solo movimentado para a abertura do sulco. O solo que eventualmente é esparramado com os discos para a entre linha não deve ser considerado.

3. Observar e contar o número de sementes que ficaram descobertas ao longo da amostra e as que ficaram entre a palha, sem o contato com o solo.

4. Dentro da distância de 3,0 metros abrir o sulco de semeadura até encontrar a semente, tomando cuidado para não removê-la do lugar ou mesmo perder a mesma. Em seguida, mede-se a profundidade de três sementes ao longo do sulco aberto, uma no começo, meio e fim da linha aberta e neste mesmo local, procurar o fertilizante e medir as profundidades em relação à superfície do solo.

5. Retirar todas sementes para a lateral do sulco de semeadura, tendo o cuidado para manter o mesmo espaçamento obtido na distribuição da máquina, verificar novamente se não ficou semente enterrada no sulco, escavando um pouco mais profundo, caso tenha ficado algumas sementes, colocar na lateral do sulco na mesma posição obtida pela distribuição da máquina. Depois de certificado de que não há mais nenhuma semente no sulco, deve-se medir o espaçamento entre 
sementes e em seguida contar o número de sementes. Registrar o número de sementes contadas;

6. A amostra de emergência de plantas deve ser realizada em até 10 dias após a semeadura, coletando-se os dados em 5,0 metros de linha para a cultura do milho. Os pontos de coleta são dispostos ao acaso, considerando-se 10 pontos no talhão e contando duas linhas para cada amostra. Depois de determinado o ponto de coleta, contar o número de plantas emergidas na linha.

7. No final do dia os formulários devem ser digitados em planilhas eletrônicas do programa Microsoft Excel ${ }^{\circledR}$ para serem armazenados no computador. 


\section{REFERÊNCIAS BIBLIOGRÁFICAS}

ACOSTA, J. J. B.; MOLIN J. P. Avaliação de protótipos de semeadoras de covas para semeadura direta. Engenharia Agrícola, v. 21, n. 1, p. 51-60, jan., 2001.

ALBRECHT, K. A terceira revolução da qualidade. HSM Manangement, p.108-112, nov/dez, 1999.

ALT, P. R. C.; MARTJNS, P. G. Administração de materiais e recursos patrimoniais. São Paulo: Saraiva, 2000. 353p.

AMERICAN SOCIETY OF AGRICULTURAL ENGINEERS - ASAE. ASAE Standards 1990. St. Joseph, Michigan. 1990. 567p.

ASSOCIAÇÃO BRASILEIRA DE NORMAS TÉCNICAS. Semeadura de precisão: ensaio de laboratório/método de ensaio, projeto de norma 12:02.06-004. Rio de Janeiro: ABNT, 1989. 21p.

BALASTREIRE, L. A. Máquinas agrícolas. São Paulo: Manole, 1990. 307p.

BONILLA, J. A. Qualidade total na agricultura. Informe Agropecuário, n. 170, p. 5659, 1991.

BORGES FILHO, E. L. O desenvolvimento do plantio direto no Brasil: a conjunção de interesses entre agricultores, industria e o estado. Campinas, 2001. 141p. Dissertação (Mestrado) - Instituto de Economia, Universidade Estadual de Campinas.

BORGES, I. D. Avaliação de épocas de aplicação da cobertura nitrogenada, fontes de nitrogênio e de espaçamentos entre fileiras na cultura milho. Lavras, 2003. 73p. Dissertação (Mestrado) - Universidade Federal de Lavras. 
BOWERSOX, D. J.; CLOSS, D. J. LOGISTICAL MANAGEMENT: the integrated supply chain process. Singapore: McGraw-Hill. International Editions, 1996. 602p.

CASÃO JUNIOR, R.; ARAÚJO, A. G.; RALISCH R. Desempenho da semeadoraadubadora MAGNUM 2850 em plantio direto no basalto paranaense. Pesquisa Agropecuária Brasileira, v. 35, n. 3, p. 523-532, mar. 2000.

CASÃO JUNIOR, R.; SIQUEIRA, R. Resultados das avaliações do desempenho de semeadoras adubadoras diretas na Costa Oeste Paranaense. Londrina: IAPAR, 2003. 134p.

CHIAVENATO, I. Administração, teoria, processo e prática. 2. ed. SÃO PAULO: Makron Books, 2000. 320p.

COELHO, J. L. D. Ensaio \& certificação das máquinas para semeadura. In: MIALHE, L. G. Máquinas agrícolas: ensaios \& certificação. Piracicaba, SP: Fundação de Estudos Agrários Luiz de Queiroz, 1996. cap. 11, p. 551-569: Ensaio \& certificação das máquinas para semeadura.

CRUZ, J. C. Manejo de solos em sucessão de culturas. In: SEMINÁRIO SOBRE A CULTURA DO MILHO SAFRINHA, 5., Barretos, 1999. Anais. Barretos: CATI/IEA, 1999. p. 39-49.

DELAFOSSE, R.M. Máquinas semeadoras de grano grueso. Santiago : FAO, 1986. 48p.

DEPONTI, C. M.; ECKERT, C.; AZAMBUJA, J. L. B. Estratégia para construção de indicadores para avaliação da sustentabilidade e monitoramento de sistemas. Agroecologia e Desenvolvimento Rural Sustentável, v. 3, n. 4, p. 44-51, out./dez., 2002.

DODSON, M. S. Avaliação da influência de indicadores de qualidade no custo operacional de um sistema de produção de milho Zea mays (L).: estudo de caso da semeadura. Jaboticabal, 1998. 80p. Monografia (Graduação) - Faculdade de Ciências Agrárias e Veterinárias, Universidade Estadual Paulista “Julio de Mesquita Filho”. 
DOURADO NETO, D., FANCELLI, A.L.; LOPES, P.P. Milho: população e distribuição de plantas. In: FANCELLI, A.L.; DOURADO NETO, D. (Ed.) Milho: tecnologia da produtividade. Piracicaba: FEALQ, 2001, p.120-125.

FARINHA. Administração de sistemas de informação I. www.salesianolins.br/\%7Enotas/apostilas/Graduacao/Farinha. 11p. (18 nov. 2004).

FEDERAÇÃO BRASILEIRA DE PLANTIO DIRETO NA PALHA - FEBRAPDP. 2005. www.febrapdp.org.br/area_PD_Brasil_2002 (29 mar. 2005).

FUNDAÇÃO PARA O PRÊMIO NACIONAL DA QUALIDADE - FPNQ Planejamento do sistema de medição do desempenho: relatório do comitê temático. 2 ed. São Paulo: FPNQ, 2002. 97p.

FURHMANN, J. G. Modelo de avaliação do nível de desempenho de um sistema de distribuição física para pequenas e médias empresas a partir da aplicação em uma indústria de eletrodomésticos. Florianópolis, 2003. 108p. Dissertação (Mestrado) Universidade Federal de Santa Catarina.

GADANHA JÚNIOR, C. D.; MOLIN, J. P.; COELHO, J. L. D. et al. Máquinas e Implementos Agrícolas do Brasil. São Paulo: NSI/IPT E CIENTEC, 1991. 468p.

GUIA PARA PLANTIO DIRETO. Ponta Grossa: Federação Brasileira de Plantio Direto na Palha, 2000. 110p.

HARRINGTON, J. Gerenciamento total da melhoria contínua. São Paulo: Makron Books, 1997. 494p.

HRONEC, J. Sinais vitais. São Paulo: Makron Books, 1997. 240p.

KACHMAN, S. D.; SMITH. J. A. Alternative measures of accuracy in plant spacing for planters using single seed metering. Transactions of the ASAE, v. 38, n. 2, p.379387, 1995.

KAPLAN, R. S.; NORTON, D. P. A estratégia em ação: balanced scorecard. Trad. de L. E. T. F. Filho. Rio de Janeiro: Elsevier, 1997. 344p. 
KIYAN, F. M. Proposta para desenvolvimento de indicadores de desempenho como suporte estratégico. São Carlos, 2001. 107p. Dissertação (Mestrado) - Escola de Engenharia de São Carlos, Universidade de São Paulo.

KURACHI, S. A. H.; SILVEIRA, G. M.; COSTA, J. A.; et al. Código de avaliação de semeadoras e/ou adubadoras. Campinas: Instituto Agronômico de Campinas, 1986. 138p. (Documentos, IAC, 3)

KURACHI, S.A.H.; COSTA, J.A. de S.; BERNARDI, J.A. et al. Avaliação tecnológica de semeadoras e/ou adubadoras: tratamento de dados de ensaios e regularidade de distribuição longitudinal de sementes. Bragantia, v. 48, n. 2, p. 249-262, 1989.

KURACHI, S.A.H.; COSTA, J.A.de S.; BERNARDI, J.A. et al. Avaliação tecnológica: resultados de ensaios de mecanismos dosadores de semeadoras-adubadoras de precisão. Campinas: IAC, 1993. 46p. (IAC. Boletim Científico, 28).

LANDERS, J. N. Fascículo de experiências de plantio direto no cerrado. 2. ed. Goiânia: APDC, 1995. 261 p.

LANDERS, J. N. Situação do plantio direto. Modulo 1 do curso de Especialização por tutoria a distância. Programa de suporte técnico à gestão de recursos hídricos. Brasília: UNB/ABEAS, 1998. 94p.

LANDERS, J, N. Histórico, características e benefícios do plantio direto. Brasília: ABEAS, 2005. 113p. (Módulo 1)

LAPOLLI, P.C. Implantação de sistemas de informações gerenciais em ambientes educacionais. Florianópolis, 2003. 98p. Dissertação (Mestrado) - Universidade Federal de Santa Catarina.

MAHL, D.; GAMERO, C. A.; BENEZ, S. H. et al. Demanda energética e eficiência da distribuição de sementes de milho sob variação de velocidade e condição de solo. Engenharia Agrícola, v. 24, n. 1, p. 150-157, jan./abr. 2004.

MANAS, A.V. Administração de sistemas de informação. 2. ed. São Paulo: Erica, 1999. 178p. 
MANTOVANI, E. C.; BERTAUX, S.; ROCHA, F. E. C. Avaliação da eficiência operacional de diferentes semeadoras-adubadoras de milho. Pesquisa Agropecuária Brasileira, v. 27, n. 12, p. 1579-1586, dez., 1992.

MARTINS, R. A.; COSTA NETO, P. L. O. Indicadores de desempenho para a gestão pela qualidade total: uma proposta de sistematização. Gestão \& Produção, v.5, n.3, p. 298-311, dez. 1998.

McGEE, J. V. Gerenciamento estratégico da informação: aumente a competitividade e a eficiência de sua empresa utilizando a informação como uma ferramenta estratégica / James McGee, Laurence Prusak; Trad. de A. B. de Figueiredo. Rio de Janeiro: Campus, 1994. 244p.

MOREIRA, D. A. Administração da produção e operações. 2. ed. São Paulo: Pioneira, 1996a. 619p.

MOREIRA, D. A. Dimensões do desempenho em manufatura e serviços. São Paulo: Pioneira, 1996b. 111p.

NAURI, M. H. C. As medidas de desempenho como base para a melhoria contínua de processos: o caso da Fundação de Amparo à Pesquisa e Extensão Universitária (FAPEU). Florianópolis, 1998. 109 p. Dissertação (Mestrado) - Universidade Federal de Santa Catarina.

OLIVEIRA, D. P. R. Como otimizar o sistema de informações gerenciais nas empresas. Revista IMES, v. 9, n. 26, p. 24-29, 1992.

OLIVEIRA, D. P. R. Sistemas de informações gerenciais: estratégicas, táticas, operacionais. 9.ed. São Paulo: Atlas, 2004. 285p.

OLIVEIRA, M. L.; VIEIRA, L. B.; MANTOVANI, E. C. et al. Desempenho de uma semeadora-adubadora para plantio direto, em dois solos com diferentes tipos de cobertura vegetal. Pesquisa Agropecuária Brasileira, v. 35, n. 7, p. 1455-1463, jul. 2000. 
ORTIZ-CAÑAVATE, J. Las máquinas agrícolas y su aplicación. 5. ed. Madrid: MundiPrensa, 1995. 157 p.

PACHECO, E. P. Avaliação de uma semeadora-adubadora de precisão com modificações do tubo condutor de sementes. Viçosa, 1994. 61p. Dissertação (Mestrado) - Universidade Federal de Viçosa.

PALHARES, M.; VIEIRA, P.A.; DOURADO NETO, D.; et al. Efeito da população de plantas e do espaçamento sobre a produtividade de milho. Revista Brasileira de Milho e Sorgo, v.2, n.3, p. 63-77, 2003.

PASQUA, S. E.; MILAN, M.; PECHE FILHO, A. Controle de qualidade em operações agrícolas mecanizadas na cultura do milho (Zea mays L.) In: CONGRESSO BRASILEIRO DE ENGENHARIA AGRÍCOLA, 25., Bauru, 1996. Resumos. Bauru: UNESP; SBEA; ALIA, 1996. p.409.

PECHE FILHO, A. Eficiência do processo operacional de semeadura direta de milho. A granja, p. 54, ago. 1999.

PEROTTONI, R.; LUCIANO, E. M.; FREITAS, H. Sistemas de informações: um estudo comparativo. www.pucrs.br/face/man/revista.htm 20p. (12 ago. 2004).

PIMENTEL-GOMES, F.; GARCIA, C. H. Estatística aplicada a experimentos agronômicos e florestais: exposição com exemplos e orientações para uso de aplicativos. FEALQ: Piracicaba, 2002. 309p.

PINTO, R. S. A. Indicadores de desempenho de frota de empresas agroindustriais canavieiras brasileiras. Piracicaba, 2002. 110p. Dissertação (Mestrado) - Escola Superior de Agricultura “Luiz de Queiroz”, Universidade de São Paulo.

PLANTIO DIRETO. Plantio direto: rumo da agricultura sustentável no Brasil. Passo Fundo, n. 49, p.15, 1999.

PRIMAVESI, A. O manejo ecológico do solo. São Paulo: Nobel, 1980. 541p. 
REIS, E. F. Inter-relação solo-semente com duas semeadoras-adubadoras de plantio direto, em diferentes umidades de um solo argiloso. Viçosa, 2000. 51p. Dissertação (Mestrado) - Universidade Federal de Viçosa.

REY, M. F. Indicadores de desempenho logístico. Revista logman, mai-jun, 1999.

RIGHeS, A. A.; CENTENO, A. S.; DALlMEYER, A. U. et al. Semeadura direta: comparação entre diferentes mecanismos sulcadores. São Paulo: IPT, 1990. 31p. (IPT. Monografia, 4).

ROBBINS, S. P. Administração: mudanças e perspectivas. São Paulo: Saraiva, 2000. 524p.

ROMEIRO, A. R. Meio ambiente e dinâmica de inovações na agricultura. São Paulo. Annablume: FAPESP, 1998. 272p.

SATURNINO, H. M.; LANDERS, J. O meio ambiente e o plantio direto. Brasília: EMBRAPA-SPI, 1997. 116 p.

SCHMOECKEL, P. S. Implantação de indicadores de performance em uma indústria metalúrgica - uma contribuição à gestão de resultados. Florianópolis, 2002. 152p. Dissertação (Mestrado) - Universidade Federal de Santa Catarina.

SILVA, J. G.; KLUTHCOUSKI, J.; SILVEIRA, P. M. Desempenho de uma semeadoraadubadora no estabelecimento e na produtividade da cultura do milho sob plantio direto. Scientia Agrícola, v. 57, n. 1, p. 7-12, jan./mar. 2000.

SILVA, M. R.; DANIEL, L. A. Tecnologia para um estande perfeito. Cultivar Máquinas, n. 33, p. 24-28, set. 2004.

SIQUEIRA NETO, M. Estoques de carbono e nitrogênio do solo e emissões de gases do efeito estufa no sistema plantio direto em Tibagi (Pr). Piracicaba, 2003. 85p. Dissertação (Mestrado) - Escola Superior de Agricultura “Luiz de Queiroz”, Universidade de São Paulo. 
STEVANATO, L.A. Compreendendo as dificuldades na implantação de um sistema gerencial: contribuição do modelo de mudança organizacional de larga escala. Caderno de Pesquisas em Administração, São Paulo, v. 1, n. 1, 6p. 1995.

SUGUISAWA, J. M.; SILVA, S. S. S.; MILAN, M. Qualidade operacional da semeadura mecanizada de milho (Zea mays L.) em sistema de plantio direto (compact disc). In: CONGRESSO BRASILEIRO DE ENGENHARIA AGRÍCOLA, 32., Goiânia, 2003. Anais. Goiânia: SBEA, 2003. 1 v.

TAKASHINA, N. T.; FLORES M. C. X. Indicadores da qualidade e do desempenho: como estabelecer metas e medir resultados. Rio de Janeiro: Qualitymark Ed., 1996. $125 p$.

USA-DoE. Department of Energy. How to Measure Performance: a Handbook of Techniques and Tools Prepared by the Training Resources and Data Exchange (TRADE) Performance. Based Management Special Interest Group (PBM . SIG). October, 1997.

VIEIRA JUNIOR, P.A. Milho. In: CASTRO, P.R.C.; KLUGE, R.A. (Ed.). Ecofisiologia dos cultivos anuais. São Paulo: Nobel, 1999. p.41-72.

VIEIRA JUNIOR, P.A.; MOLIN, J.P.; DOURADO NETO, D.; et al. Relações entre população, distribuição espacial de plantas e atributos do solo sobre o rendimento de grãos de milho (compact disc). In: CONGRESSO BRASILEIRO DE AGRICULTURA DE PRECISÃO - CONBAP, 5, 2004, Piracicaba, Anais. ESALQ, 2004, 5p. 
APÊNDICE 
Apêndice 1. Numeração correspondente as referências bibliográficas encontradas na pesquisa

\section{Número}

1

2

3

4

5

6

7

8

9

10

11

12

13

14

15

16

17

\section{AUTOR}

Acosta \& Molin (2000)

Casão Junior \& Siqueira (2003)

Casão Junior et al. (2000)

Coelho (1996)

Guia... (2000)

Kachman \& Smith (1995)

Kurachi et al. (1989)

Kurachi et al. (1993)

Mahl et al. (2004)

Mantovani et al. (1992)

Oliveira et al (2000)

Pasqua et al. (1996)

Peche Filho (1999)

Reis (2000)

Righes et al. (1990)

Silva \& Daniel (2004)

Suguisawa (2003) 